\title{
Biological mechanisms underlying evolutionary origins of psychotic and mood disorders
}

\section{AUTHOR(S):}

Goto, Yukiori; Lee, Young-A; Yamaguchi, Yoshie; Jas, Emanuel

\section{CITATION:}

Goto, Yukiori ...[et al]. Biological mechanisms underlying evolutionary origins of psychotic and mood disorders. Neuroscience Research 2016, 111: 13-24

\section{ISSUE DATE:}

2016-10

URL:

http://hdl.handle.net/2433/252320

\section{RIGHT:}

(C) 2016. This manuscript version is made available under the CC-BY-NC-ND 4.0 license http://creativecommons.org/licenses/by-nc-nd/4.0/:; この論文は出版社版でありません 。引用の際には出版社版をご確認ご利用ください。; This is not the published version. Please cite only the published version. 


\section{Biological Mechanisms Underlying Evolutionary Origins of Psychotic and Mood Disorders}

Running title: Evolutionary Perspective of Psychiatric Disorder

Yukiori Goto ${ }^{1}$, Young-A Lee ${ }^{2}$, Yoshie Yamaguchi ${ }^{1}, \&$ Emanuel Jas ${ }^{3}$

${ }^{1}$ Cognition and Learning Section, Department of Cognitive Science, Primate Research Institute, Kyoto University, Inuyama, Aichi, 484-8506, Japan

${ }^{2}$ Department of Food Science \& Nutrition, Catholic University of Daegu, Gyeongsan, Gyeongbuk, 712-702, Korea

${ }^{3}$ Graduate School of Natural Sciences, Utrecht University, Princetonplein 5, 3584 CC, Utrecht, the Netherlands

\section{Correspondence:}

Yukiori Goto, Ph.D.

Kyoto University Primate Research Institute

41-2 Kanrin

Inuyama, Aichi,

484-8506, Japan

Phone: +81568630551

E-mail: goto.yukiori.5c@kyoto-u.ac.jp

Number of Pages: 59 pages

Title: 85 characters

Running Title: 48 characters

Abstract: 131 words

Text: 7,257 words

References: 226

Figures: 0

Tables: 1

Supplementary Materials: 0

Keywords: Psychiatric disorder; Monoamine; Social hierarchy; Maternal care; Epigenetic; Neurodevelopment; Homophily; Symbiosis 


\begin{abstract}
Psychotic and mood disorders are brain dysfunctions that are caused by gene environment interactions. Although these disorders are disadvantageous and involve behavioral phenotypes that decrease the reproductive success of afflicted individuals in the modern human society, the prevalence of these disorders have remained constant in the population. Here, we propose several biological mechanisms by which the genes associated with psychotic and mood disorders could be selected for in specific environmental conditions that provide evolutionary bases for explanations of when, why, and where these disorders emerged and have been maintained in humans. We discuss the evolutionary origins of psychotic and mood disorders with specific focuses on the roles of dopamine and serotonin in the conditions of social competitiveness/hierarchy and maternal care and other potential mechanisms, such as social network homophily and symbiosis.
\end{abstract}

\title{
1. Introduction
}

Psychotic and mood disorders such as schizophrenia (SCZ) and major depressive disorder (MDD) are devastating mental problems with symptoms that include cognitive dysfunction and affective disturbance. Epidemiological studies have reported that the fecundity rates of subjects with psychotic and mood disorders are significantly lower than those of normal subjects (Power et al., 2013), which suggests that the symptoms of these disorders are disadvantageous behavioral phenotypes, at least in modern human society. Nevertheless, psychotic and mood disorders have been present at constant incidences in humans since an ancient era (Berrios, 1988; Kyziridis, 2005). A major question is why psychotic and mood disorders emerged and have been maintained at a constant prevalence in humans despite natural selection, which predicts the elimination of phenotypes that do not match the environment.

By drawing evidence together from a range of published research, we present mechanisms of gene-environment interactions that may have played roles in the selection and maintenance of alleles that increase the risks of psychotic and mood disorders in evolution. We discuss this issue with a specific focus on the roles of dopamine (DA) and serotonin (5-HT) transmission in (1) social competitiveness/hierarchy, (2) maternal care, (3) social network homophily, and (4) symbiosis.

\section{Positive Selection of Genes Associated with Psychotic and Mood Disorders}

Genetic factors play roles in psychotic and mood disorders. The heritability rates of psychiatric disorders, including psychotic and mood disorders, are estimated to be approximately 0.4-0.8 depending on the type of disorders (Eaton et al., 2008; Sullivan et al., 2012). Several genetic mechanisms may answer the questions of how and why disadvantageous alleles that increase the risks of psychotic and mood disorders have been selected for and maintained despite natural selection in evolution. These potential mechanisms are not mutually exclusive and are intermingled in terms of the causes of disorders. 
One possible explanation is that de novo mutations of genes occur rarely but yield large effects (Gratten et al., 2014; Malhotra and Sebat, 2012; Sullivan et al., 2012). Because de novo mutations may occur at a constant rate, such mutation could explain the constant prevalence of psychotic and mood disorders even given the decreased fecundity of patients (Malhotra and Sebat, 2012). Sporadic cases of SCZ and autism spectrum disorder (ASD) with no family histories have been reported (Cuccaro et al., 2003; Lewis et al., 1987; Roy and Crowe, 1994), and de novo mutations may play significant roles in such cases. However, because the frequency of de novo mutations is extremely low, it is estimated that only a fraction of cases at most can be explained by de novo mutations (Gratten et al., 2014; Malhotra and Sebat, 2012; Sullivan et al., 2012). Thus, other mechanisms should also be involved.

The neutral selection of genes (Kimura, 1968; Kimura and Ohta, 1971) is another possible explanation. The effect of each allele associated with psychotic and mood disorders is too small to yield either an advantageous or disadvantageous influence, and the allele consequently escapes the selection process. However, when these alleles with small effects are combined, symptomatic conditions may emerge. Common genetic variants with small effect sizes that increase the risks (odds ratios) of psychiatric disorders, including psychotic and mood disorders, by approximately 1.05-1.2 at most have been identified (Gratten et al., 2014). Such common alleles are estimated to account for $30-50 \%$ of cases due to the accumulated contributions of multiple alleles (Gratten et al., 2014). Ripke and colleagues estimated that $50 \%$ of SCZ cases could be explained by 8,332 single nucleotide polymorphisms (SNPs) (Ripke et al., 2013).

An alternative explanation depends on the notion that an allele or a set of alleles associated with psychotic and mood disorders yield small but significant effects that are disadvantageous and thereby subjected to natural selection; however, such disadvantageous phenotypes are maintained by balancing selection because they can also function advantageously in specific environmental conditions.

Explorations of the evolutionary origins of human diseases have been attempted in the field of evolutionary medicine (Gluckman et al., 2011). Evolutionary medicine is distinct from conventional biomedical research in that it emphasizes the understanding of "why" rather than "how" diseases are caused. Trade-offs in biological function during evolution are thought to be involved in many human diseases. For example, erect bipedalism enabled free hand use in hominids, but the trade-offs include diseases such as thrombophlebitis and herniated lumber vertebral disks (Haeusler et al., 2013). The loss of urase oxidase activity in several species, including humans and non-human primates, resulted in prolonged longevity due to the anti-oxidant effects of uric acid; however, the accumulation of uric acid also causes gouty arthritis (Johnson et al., 2009).

Environments are critical determinants of the selection of genetic variants based on the behavioral phenotypes that result from mutations. The sickle cell trait is caused by nonsynonymous mutations of the $\beta$-globin gene that result in amino acid sequence changes that alter red blood cell structure and function (Rees et al., 2010). Sickle cell disease occurs in various types that are determined by the parts of the $\beta$-globin in which the mutations occur (Rees et al., 2010). The most common mutation is caused by an A --> T SNP that results in the replacement of glutamic acid with valine (Rees et al., 2010). Sickle cell mutation homozygosity is often lethal, and 
heterozygotes suffer from disadvantageous phenotypes that include anemia. Nevertheless, a high prevalence of this genotype has been maintained in malaria epidemic regions in Africa, because this genotype confers resistance to malaria infection (Beutler et al., 1955). Thus, specific environmental factors can preserve genotypes associated with diseases that are disadvantageous in normal conditions.

Whether psychotic and mood disorders involve balancing selection forces similar to those that affect sickle cells remains unknown. Nevertheless, because environmental risk factors such as stress play significant roles in most if not all psychotic and mood disorders (Burt, 2009; Hammen, 2005; Lewis and Levitt, 2002; Rabkin, 1980; Schmitt et al., 2014), the mechanisms that sufficiently explain the causes of psychotic and mood disorders should be considered within the framework of gene-environment interactions with or without epigenetic mechanism and not in the framework of genetic variants alone.

\section{Are Psychotic and Mood Disorders Uniquely Nested in Human Evolution?}

A study by Crespi and colleagues (Crespi et al., 2007) demonstrated that traces of positive selection, selective sweep (i.e., reductions in genetic variations in the vicinity of variants under positive selection due to hitch-hiking effects among population (Nielsen et al., 2007)) and the $\mathrm{dN} / \mathrm{dS}$ ratio (i.e., the ratio of non-synonymous to synonymous variants (Kimura, 1977)) are found approximately twice more frequently among SCZ candidate genes than other control genes (i.e., those associated with neuronal activity). Additionally, a study by Ogawa and Vallender revealed that the $\mathrm{dN} / \mathrm{dS}$ ratios of the genes that are homologous to SCZ and ASD candidate genes are significantly higher in catarrhini (old world monkeys, anthropoids, and humans) and cetacea (dolphins and whales) than other species of animals, which suggests that the alleles associated with SCZ and ASD have been subjected to positive selection and have played important roles in the evolutions of the brains of species such as catarrhini and cetacea with brain sizes that are larger than those of other species (Ogawa and Vallender, 2014). If such alleles are involved in the expansion of the size of the brain, this finding would explain how catarrhine primates and cetaceans acquired superior social intelligence.

Whether psychotic and mood disorders are unique human conditions that are not present in other animals essentially remains unknown because no systematic research has been conducted to answer this question. However, behavioral manifestations that are highly similar to MDD-like states have often been observed in captive macaques (Camus et al., 2014; Xu et al., 2015), which suggests that some psychotic and mood conditions may not be exceptional in humans but rather might extend to at least some non-human animals such as catarrhine primates. More importantly, psychotic and mood disorders are often characterized not only by deficits of higher brain function but also by more rudimentary behavioral traits that are observed across different animal species, such as impulsivity, aggression, stereotypy, and anxiety. These behavioral traits consist of core symptoms and are quite often observed across different categories of psychiatric disorders, including psychotic and mood disorders (Ouzier, 2013). Given that these behavioral traits are found in animal species other than those of catarrhini and cetacea, the evolutionary origins of some aspects of psychiatric symptoms, such as impulsivity and aggression, may not necessarily be 
limited to Homo species.

\section{Social Competitiveness/Hierarchy as an Evolutionary Origin of Psychotic and Mood Disorders}

Here, we discuss trade-offs similar to those associated with sickle cells that may have been established between DA- and 5-HT-dependent cognitive/affective function and some behavioral traits that are associated with psychotic and mood disorders. Specifically, impulsivity and aggression may work advantageously in specific conditions, such as those related to social competitiveness and consequent social hierarchical organization. Thus, the alleles of the DA and 5-HT genes that are associated with increased risks of psychotic and mood disorders may have been maintained among animals and humans living in hierarchical societies through balancing selection.

Humans and most other animals live in social groups that yield various benefits such as the facilitation of reproduction and protection from predators by cooperation among subjects in the groups. In many cases of such social groups, social hierarchy exists as an emergent property that results from competition among individuals, although recent evidence also suggests that social hierarchy could be a mechanism with more self-organizing adaptive features that are determined by differences in individual attributes and social interaction dynamics (Chase et al., 2002; Corominas-Murtra et al., 2013; David-Barrett and Dunbar, 2012; Franz et al., 2015; Hobson and DeDeo, 2015). The tolerance of social hierarchy varies between species; some species organize very strict social hierarchies, whereas other species exhibit more relaxed social hierarchies (Thierry, 2007). Human social systems are substantially different from those of many primates in pair-bonding, paternal care, cooperative breeding and an unusually high level of social cooperation. Indeed, because the invention of agriculture and pastoralism, humans have adopted a sedentary lifestyle and have gradually progressed into more stratified, non-egalitarian social systems. Nevertheless, during human evolution, humans have definitely been exposed to very severe competition in many different aspects both within group and between groups. In particular, the social hierarchy of humans, especially that of young children, has been demonstrated to be substantially similar to that of non-human primates (Hawley, 1999; Koski et al., 2015), which suggests that mutual biological mechanisms may play roles in the social hierarchies of both human children and non-human primates. Although reproductive success is not solely determined by social dominance but rather involves various factors, meta-analyses and reviews of the literatures have clearly demonstrated that social dominance is one of the most important factors in terms of the reproductive success in non-human primates (Ellis, 1995; Gowlishaw and Dumbar, 1991; Majolo et al., 2012), and this is true even in species that have highly relaxed hierarchies such as Assamese macaques (Schulke et al., 2010). Although social hierarchy is strongly associated with reproductive success in males, this is less clear in females (Ellis, 1995), such that the following arguments about the roles of social competitiveness and consequent social hierarchy in the selection of psychotic and mood disorder-associated genotypes may be mostly applicable to males.

Investigations seeking to understand the biological mechanisms that underpin social competitiveness and the construction of social hierarchies have been conducted in various species of animals and humans. Among the many factors that are involved in 
social hierarchy (Koski et al., 2015), behavioral traits such as aggression and impulsivity have been demonstrated to play important roles in determining social class and hence can play crucial roles in attaining a high level of reproductive success. Thus, animals such as non-human primates and rodents (Ferrari et al., 1998; Machida et al., 1981; Morgan et al., 2000) and impulsivity (Fairbanks et al., 2004) have been shown to be placed in higher the social class in their groups. Even in humans, aggression and impulsivity should have played crucial roles in severe contexts such as tribal warfare, which must have been quite frequent during human evolution, although it does obviously depend on the situation. This notion is particularly interesting because impulsivity and aggression work advantageously in gaining higher social class, but these behavioral traits are treated as disadvantages in the modern human society and are associated with various psychiatric disorders including psychotic and mood disorders (Courtet et al., 2011; Mann et al., 2009; Robbins et al., 2012).

\section{1. $D A$}

Mesocortical and mesolimbic DA innervations from the ventral tegmental area into the prefrontal cortex (PFC) and nucleus accumbens (NAcc), respectively, play crucial roles in brain function such as reinforcement learning, goal-directed behavior, and cognitive functions, such as working memory, sustained attention, and behavioral flexibility (Dunnett and Robbins, 1992; Grace et al.; Seamans and Yang, 2004). DA deficits have been implicated in SCZ (Howes and Kapur, 2009). Antipsychotic drugs for the treatment of SCZ have DA D2 receptor antagonistic properties (Seeman, 2011), although no consistent results related to D2 receptor expression changes have been reported in postmortem or functional imaging studies of patients (Davis et al., 1991; Howes and Kapur, 2009; Kambeitz et al., 2014; Sedvall, 1990; Soares and Innis, 1999). Positron emission tomography (PET) imaging studies in SCZ patients have also reported alterations of PFC D1 receptor availability, although the results are inconsistent and include a mixture of findings demonstrating increases (Abi-Dargham et al., 2012; Poels et al., 2013), decreases (Kosaka et al., 2010; Okubo et al., 1997), or no change (Kambeitz et al., 2014; Karlsson et al., 2002) in D1 receptor availability.

Accumulating evidence suggests that DA transmission is involved in the organization of social hierarchy. The dopamine transporter (DAT) plays a primay role in the regulation of nigrostriatal and mesolimbic DA release (Kuhar et al., 1990). Following the development of DAT knockout mice, the functional significance of DAT in the cognitive and affective domains has been extensively investigated in rodents (Gainetdinov, 2008). Social groups consisting of DAT knockout mice have been demonstrated to organize more unstable hierarchies relative to groups of normal mice (Rodriguiz et al., 2004). The cerebrospinal fluid (CSF) concentration of the DA metabolites homovanilic acid has also been found to be higher in subordinates than dominants (Nader et al., 2012). A study using a socially housed non-human primate model of parkinsonian with MPTP-treatments demonstrated a shift of social rank in the middle class monkey in the group following a low-dose MPTP administration, and this monkey returned to its original rank following a high-dose MPTP administration (Durand et al., 2015).

The roles of D1 receptor signaling in cognitive function and PFC information processing have been extensively investigated and well characterized (Seamans and Yang, 2004). For example, the local infusion of a D1 antagonist into the PFC of 
non-human primates (Goldman-Rakic et al., 2000) and rodents (Seamans et al., 1998) has been demonstrated to impair working memory and disrupt the sustained firing of PFC neurons during delay periods in a working memory task. The administration of a D1 antagonist also impairs other domains of cognitive function, such as behavioral flexibility (Ragozzino, 2002) and associative learning (Puig et al., 2014). In humans, two SNPs, i.e., rs4532 (A-48G) and rs5326 (G-94A), in the 5'UTR of the DRD1 gene have been identified. The associations of these SNPs with increased risks of SCZ are controversial; a meta-analysis of the SZGene database reported no association (Allen et al., 2008), but another meta-analysis of the literatures reported a weak association with the DRD1 gene variant rs5326 (Pan et al., 2014).

Although low D1 receptor function impairs cognitive function, it could facilitate fitness benefits of individuals living in a hierarchical social system. A human PET imaging study has demonstrated that limbic and striatal D1 receptor availabilities are positively correlated with social affiliation and negatively correlated with social dominance and aggression such that subjects with higher D1 receptor availability are less dominant and aggressive and more affiliative with others (Plaven-Sigray et al., 2014). Among rodents, one mouse strain, i.e., BALB/c mice, exhibit more aggressive behavior than another strain, i.e., A/J mice. This difference is correlated with lower PFC and striatal D1 receptor expression in the BALB/c mice than the $\mathrm{A} / \mathrm{J}$ mice (Couppis et al., 2008). In addition, the administration of a D1 antagonist to rats has been found to induce frequent impulsive choices in a delayed-discounting task (van Gaalen et al., 2006). Collectively, it is possible that a trade-off might have been established between cognitive function and behavioral traits, such as impulsivity and aggression, which are important determinants of the social class of individuals in the hierarchy such that genetic variants that determine D1 receptor function may have been subjected to balancing selection through evolution.

DA D2 receptor signaling also plays important roles in cognitive function. In human studies, D2 agonist treatments have been found to enhance working memory (Kimberg et al., 1997; Luciana et al., 1992; Muller et al., 1998) and behavioral flexibility (van Holstein et al., 2011), although these effects depend on working memory capacity (Kimberg et al., 1997) and the genetic backgrounds (van Holstein et al., 2011) of the subjects. A number of DRD2 SNPs have been identified and associated with increased risks of SCZ and mood disorders (Zou et al., 2012). Meta-analyses and large-scale genome-wide association studies (GWAS) have demonstrated significant associations of several DRD2 SNPs, i.e., rs2514218 (Schizophrenia Working Group of the Psychiatric Genomics, 2014), rs1801028 (Ser311Cys) (Glatt and Jonsson, 2006; Liu et al., 2012; Yao et al., 2015), rs6277 (C957T) (Betcheva et al., 2009; Fan et al., 2010a; Monakhov et al., 2008), and rs1799732 (-141 Ins/Del) (Cordeiro et al., 2009), with increased risks of SCZ. The functional significance of another DRD2 SNP, i.e., rs1800497 (TaqIA), has been extensively investigated (Grandy et al., 1989; Noble, 2003). A1-allele carriers exhibit lower striatal D2 receptor availability than A2-allele carriers (Pohjalainen et al., 1998; Thompson et al., 1997), which is linked to social problems such as extraverted personalities (Smillie et al., 2010). Although a recent meta-analysis did not support the association of this SNP with SCZ (Yao et al., 2015), another meta-analysis concluded that there is an association with mood disorders (Zou et al., 2012). Although the A1 allele would work disadvantageously in social function, the percentage of A1-allele carriers differs among ethnic groups. Higher prevalence 
$(\sim 40 \%)$ is present in Asians and African-American than in Europeans ( $20 \%)$, and the prevalence could reach up to $80 \%$ in American-Indians (Goldman et al., 1993; Roman et al., 2013), which suggests that the A1-allele has been under evolutionary pressures in social environments that could vary among different ethnic groups. However, the aspects of the social environments that play roles in the selection of this genotype have remained unclear. The high prevalence of the A1 allele in American-Indians may also involve a bottleneck effect (i.e., significant reduction of the population size in the past) due to European colonization (O'Fallon and Fehren-Schmitz, 2011).

D2 receptor signaling is also involved in social hierarchy. PET imaging in cynomolgus monkeys has revealed that there is no significant difference in D2 receptor availability in the striatum when monkeys are individually housed. However, striatal D2 receptor availability becomes significantly higher in dominants than in subordinates when they are housed in a social group (Morgan et al., 2002). In contrast, striatal D2 receptor availability is positively correlated with social dominance (Cervenka et al., 2010) and social status (Martinez et al., 2010), and negatively correlated with social affiliation (Cervenka et al., 2010), such that subjects with higher D2 availability are more dominant over others and experience higher socioeconomic status. Collectively, D2 receptor function plays roles in social hierarchy, but it yields the opposite effects compared to those of D1 receptor function. Thus, individuals with low D1 and high D2 receptor signaling are more likely to be of higher social class (dominants), whereas subjects with high D1 and low D2 receptor signaling are more likely to be of lower social class (subordinates). Higher D2 receptor function is better for both cognitive function and social hierarchy, such that no apparent trade-off between social hierarchy and cognitive function in terms of D2 receptor function have been observed. Nevertheless, there are several individual fitness benefits of lower D2 receptor signaling for lower social class subjects in a hierarchy. We provide two such examples in relation to (1) novelty seeking and (2) creativity.

First, D2 receptor function is associated with novelty seeking. Studies in humans and rodents have demonstrated that subjects with lower D2 receptor expression or availability in brain regions such as the insula (Suhara et al., 2001), midbrain DA nuclei (Zald et al., 2008), and striatum (Tournier et al., 2013) exhibit greater the novelty seeking. The A1 allele of the DRD2 TaqIA polymorphism has also been associated with greater novelty seeking in drug-addicted people (Han et al., 2008; Lin et al., 2007; Teh et al., 2012) and normal subjects (Noble et al., 1998) (but also see (de Brettes et al., 1998) that reported no association) than non-allele carriers. Novelty seeking works advantageously to individuals living in a hierarchical social group, especially when the group becomes over-populated. Because the priority for accessing resources (e.g., foods) is given to subjects in the dominant class, the subordinates are unable to secure resources when the number of subjects in the group exceeds the capacity that the resources allow. The behavioral tendency toward high novelty seeking would lead to exploration for resources outside of the group in such conditions.

Second, D2 receptor function is also associated with creativity. In normal human subjects, lower D2 receptor availability in the thalamus is associated with higher creativity (de Manzano et al., 2010). A genetic study has also reported that the DRD2 TaqIA polymorphism A1 allele is associated with creativity (Reuter et al., 2006; Zhang et al., 2014). Consistent with these findings, a number of studies in different species of animals, such as hyenas (Benson-Amram and Holekamp, 2012) and pigeons (Bouchard 
et al., 2007), have demonstrated that creativity as measured by a variety of behavioral patterns exhibited during problem solving (e.g., taking chow out of an enclosed cage) is richer in animals that exhibit greater novelty seeking. Indeed, creativity could aid the overcoming of intra-group conflictions and could enhance reproductive success of groups of low social class subjects.

Although highly speculative, the roles of D2 receptor function in social hierarchy along with behavioral traits, such as creativity and novelty seeking, may be able to explain evolutionary origins of SCZ. First, novelty seeking for finding resources outside of the group by low social class subjects may eventually split the group. This notion may be consistent with the group splitting hypothesis of SCZ proposed by Stevens and Price (Stevens and Price, 2000), which argues that SCZ traits are often observed in charismatic leaders who can lead and split a group when the group becomes too large. Second, lower D2 receptor availability in the thalami of SCZ patients than normal subjects has been demonstrated (Yasuno et al., 2004). The greater creativity of SCZ patients has also been demonstrated using Lovibond sorting test in which participants sort objects while the participants themselves create categories and creativity is assessed according to the number of invented sorting categories. In this test, SCZ patients generate more categories than normal subjects. In contrast, SCZ patients perform poorly in similar sorting tests in which the sorting is based on pre-designed rules, such as the Wisconsin card sorting test (Dykes and McGhie, 1976). Linkds between creativity and SCZ have also emerged from epidemiological and genetic studies. A prospective epidemiological study of 1.2 million Swedish people over 40 years demonstrated that relatives, such as parents and siblings, of SCZ patients are more likely to hold creative jobs, although the patients themselves do not have such jobs (Kyaga et al., 2013). A recent GWAS also demonstrated that SCZ susceptibility genes are also associated with creativity (Power et al., 2015). Investigations of the associations between DA function, social hierarchy, novelty seeking, and creativity would provide a novel insights into the biological mechanisms of SCZ.

\subsection{5-HT}

The transmission of 5-HT in the corticolimbic system plays important roles in affective function (Dayan and Huys, 2009; Hariri et al., 2006). MDD is a mood disorder with affective dysfunction and its pathophysiology is thought to involve decreased 5-HT transmission in several brain regions including the hippocampus and PFC because selective serotonin reuptake inhibitors (SSRIs) exhibit therapeutic efficacy in MDD (Clark et al., 2009; Elliott et al., 2011; Kupfer et al., 2012), and serotonin transporter availability is higher in the thalami of MDD than normal subjects (Ichimiya et al., 2002). However, there are also controversial studies that have reported lower serotonin transporter availability in the PFC of MDD patients than in healthy subjects (Mann et al., 2000; Meyer et al., 2004), which suggests that alterations in 5-HT transmission associated with MDD are complex and region-specific.

A 44-bp deletion/insertion variable number tandem repeat (VNTR) that generates 14 (s-allele) or 16 (l-allele) repeat variants in the promoter region of the serotonin transporter gene (SLC6A4) has been identified and is referred to as the serotonin transporter-linked polymorphic region (5HTTLPR) (Lesch et al., 1994). The s-allele has been associated with lower transcriptional serotonin transporter activity and therefore lower 5-HT reuptake than the 1-allele (Heils et al., 1996). Meta-analyses 
have demonstrated a weak but significant association of the s-allele with an increased risk of mood disorders including MDD (Clarke et al., 2010; Lasky-Su et al., 2005; Lotrich and Pollock, 2004). The tryptophan hydroxylase is a rate-limiting enzyme in 5-HT synthesis (Mandell and Knapp, 1982). The tryptophan hydroxylase gene is located at two loci, one in chromosome 11p15.3-14 and the other in 12q21.1, which are denoted as TPH1 and TPH2, respectively (Bennett et al., 2000). Several SNPs have been identified in both TPH1 and TPH2, among which rs1800532 (A218C) (Gatt et al., 2015; Gizatullin et al., 2006) and rs4570625 (G703T) (Gao et al., 2012) have been associated with mood disorders.

Human and non-human primate studies have demonstrated somewhat controversial roles of 5-HT in social hierarchies. In human studies, the administration of SSRIs that increases 5-HT transmission has been found to facilitate social affiliation (Knutson et al., 1998). In contrast, another study involving the oral administration of tryptophan, which increases central nervous system 5-HT synthesis and metabolism (De Simoni et al., 1987) and thereby may in turn increase 5-HT transmission, demonstrated increased social dominance (Moskowitz et al., 2001). Thus, these two intuitively confronting traits were facilitated by increased 5-HT transmission. In non-human primates living in social groups, higher CSF levels of the 5-HT metabolite 5-hydroxyindoleacetic acid (5-HIAA) were found in subordinates than dominants (Riddick et al., 2009). Studies have also demonstrated that with higher CSF 5-HIAA concentrations, rhesus macaques exhibit less aggressive behavior (Westergaard et al., 2003), whereas vervet monkeys exhibit less impulsive behavior (Fairbanks et al., 2001), which predicts lower social class in these two species. In contrast, another study found that the administration of drugs that increase and decrease 5-HT transmission to a pair of non-human primates results in a dominant status in the subject who receives the drug that increases 5-HT release and a subordinate status in the other subject who receives a drug that decreases 5-HT release, which suggests that higher 5-HT transmission is important for higher social class (Raleigh et al., 1991). These controversial findings can be reconciled by considering the distinct roles of 5-HT transmission in social dominance between high and low social class subjects. Larson and Summers reported that the administration of SSRIs to a dominant males Anolis carolinensis attenuated dominance over subordinates, whereas the same treatment applied to the subordinates attenuated submission toward dominants (Larson and Summers, 2001). A similar finding has also been reported in a recent study with cynomolgus monkeys; the administration of SSRIs to the dominants and subordinates attenuated dominant and submissive behaviors, respectively (Shively et al., 2014). Consistent with these studies, 5-HT gene polymorphisms have also been associated with the rigidity of the social hierarchies of macaque species. The prevalence of alleles that result in low 5-HT transmission is higher in macaque species that organize strict social hierarchies than in species with relaxed social hierarchies (Canli and Lesch, 2007). These studies suggest that low 5-HT transmission is clearly disadvantageous in high social class subjects, whereas low 5-HT transmission yields beneficial effects in low social class subjects. Because low 5-HT transmission is associated with affective dysfunction and MDD, alleles that result in low 5-HT signaling and increased risks of MDD may have been maintained through balancing selection among low social class subjects living in the hierarchical social systems. 


\section{Maternal Care as an Evolutionary Origin of Psychotic and Mood Disorders}

Psychotic and mood disorders involve neurodevelopmental deficits (Ansorge et al., 2007; Arnsten and Rubia, 2012; Lewis and Levitt, 2002; Mullin et al., 2013). Here we discuss a potential mechanism by which the neuordevelopmental process could be an important determinant for the selection of alleles associated with psychotic and mood disorders. Specifically, studies have demonstrated that maternal care deprivation and physical abuse in early development result in the selection of alleles associated with increased risks for psychotic and mood disorders (Belsky and Hartman, 2014; Belsky et al., 2009; Homberg and Lesch, 2011).

Monoamine oxidase A (MAOA) is an enzyme that is located on the membrane of the mitochondria in presynaptic terminals and is involved in the degradation of 5-HT, DA, and norepinephrine (Chajkowski-Scarry and Rimoldi, 2014). The promoter region of the MAOA gene has a 30-bp untranslated or upstream VNTR ( $\mu$ VNTR) that varies between 3, 3.5, 4, and 5 repeats (Sabol et al., 1998). MAOA activity is higher with the 3.5 and 4 repeats (h-allele) than the 3 and 5 repeats (l-allele) (Sabol et al., 1998). Meta-analyses have demonstrated associations of the 1-allele with increased risks of mood disorders (Fan et al., 2010b), but not SCZ ( $\mathrm{Li}$ and $\mathrm{He}, 2008$ ). In macaques, 5, 6, or 7 repeats of the 18-bp VNTR that is orthologous to that of humans in the promoter region of the MAOA gene have also been identified (Newman et al., 2005). Transcriptional activity is lower (thereby resulting in high DA and 5-HT transmission) with the 7-repeat allele (1-allele) compared with the 5- or 6-repeat allele (h-allele) (Newman et al., 2005). A study by Newman and colleagues demonstrated that rhesus macaques with the 1-allele are more aggressive and competitive for food access than those with the h-allele when they are reared with normal maternal care (Newman et al., 2005). However, when macaques are raised under conditions of maternal care deprivation, this relationship is reversed; thus, the monkeys with the 1-allele exhibit more aggressive and competitive behaviors than those with the s-allele. Similar alterations have also been reported in humans (Enoch et al., 2010; Hill et al., 2013; Huizinga et al., 2006; Kim-Cohen et al., 2006; Wakschlag et al., 2010). Children with the l-allele exhibit more severe antisocial behaviors, emotional problems, attention deficits, and hyperactivity than h-allele carriers when these children are reared in a normal maternal care conditions, whereas these tendencies are reversed among children who have experienced opposite physical abuse; the h-allele carriers exhibit more problems than the 1-allele carriers.

5HTTLPR s-allele carriers also exhibit greater aggression and a higher incidence of MDD than 1-allele carriers when they grow in conditions of normal maternal care; however, 1-allele carriers are more aggressive and susceptible to MDD than s-allele carriers when are reared by caregivers and receive less maternal care (Belsky et al., 2009; Cicchetti et al., 2007; Humphreys et al., 2015). In macaques, similar interactions between early adverse rearing conditions and functional alterations of the 5HTTLPR homologous to that of humans in the stress response (Barr et al., 2004) and visual orientation (Champoux et al., 2002) have also been reported.

The DRD4 gene has a 48-bp VNTR in exon 3 that ranges from 2 to 11 repeats, and 4 and 7 repeats are the most common (Van Tol et al., 1992). Since the initial finding by LaHoste and colleagues (LaHoste et al., 1996), the 7-repeat (or longer) allele has been associated with an increased risk of ADHD, although this association has often 
been controversial in subsequent studies (Faraone et al., 2001; Gonon et al., 2012; Hawi et al., 2000; Sullivan et al., 1998). Meta-analyses have reported an association between the DRD4 VNTR and an increased risk of mood disorders (Lopez Leon et al., 2005) but not SCZ (Glatt et al., 2003b). The DRD4 genotype has also been associated with high novelty seeking (Ebstein et al., 1996). The prevalence of the 7-repeat allele and longer allele is significantly higher ( $50-70 \%)$ among nomadic settlements that migrated from northern Asia to the Americas than sedentary settlements $(\sim 10-15 \%)$; thus, the 7-repeat allele has been suggested to contribute to cross-continental macro-migration in relation to its association with high novelty seeking (Chen et al., 1999; Matthews and Butler, 2011). The associations between the DRD4 allele and cognitive and affective function have been less explored and remain unclear. Nevertheless, children with fewer than seven repeats have been demonstrated to perform better in cognitive tests, such as the Stroop test and continuous performance test, and to exhibit less externalizing behavior and less aggressive and impulsive behavior than those with 7 repeats or more; however, these relationships are reversed in children who receive less maternal care than normal cases (Bakermans-Kranenburg and van Ijzendoorn, 2006; Berry et al., 2014).

DRD2 TaqIA polymorphism is also subjected to functional alterations in response to adverse rearing conditions during early development. Thus, DRD2 A1 allele-carriers who are reared with poor maternal care exhibit greater novelty seeking than A1 allele-carriers who are reread with normal maternal care; however, this effect is absent in non-A1 allele-carriers (Keltikangas-Jarvinen et al., 2009).

Catechol-o-methyltransferase (COMT) is a soluble (sCOMT) or membrane-bound (mbCOMT) enzyme that regulates DA release by catabolizing DA molecules (Elsworth et al., 1987; Karoum et al., 1994), and its roles has been specifically suggested in the mesocortical DA pathway innervating into the prefrontal cortex (PFC) (Gasparini et al., 1997; Liljequist et al., 1997). The COMT gene has a functional SNP (rs4680) at codon 158 that results in the replacement of valine with methionine (Val158Met) in humans. COMT with valine exhibits higher activity that consequently lowers the extracellular DA concentration compared with COMT with methionine (Dickinson and Elvevag, 2009; Malhotra et al., 2002; Meyer-Lindenberg et al., 2006). Given the Yerkes-Dodson relationship of mesocortical DA function (i.e., both DA transmission too high and too low causes deficits) (Seamans and Yang, 2004), it is difficult to determine which allele works advantageously for PFC function. However, meta-analyses of the influence of the COMT Val158Met polymorphism on cognitive function have revealed that although the effects are very weak and marginal at best, Met allele carriers perform better on cognitive tasks, such as working memory tasks (Barnett et al., 2008) and Wisconsin card sorting test (Barnett et al., 2007) than Val-allele carriers. Meta-analyses have not found a significant association between the COMT Val158Met polymorphism and an increased risk of SCZ (Munafo et al., 2005). In one meta-analysis, an association was still found when the analysis was conducted with a stratification of the studies according to the ethnicity of the patients (Glatt et al., 2003a), whereas another meta-analysis did not find an association even with such ethnicity stratification (Fan et al., 2005). The COMT Val158Met polymorphism has also been demonstrated to be influenced by maternal care in early development. In one study, children with the Val allele were found to be more aggressive than those with the Met allele; however, this relationship was reversed in offspring born to mothers who 
frequently smoked during pregnancy (Brennan et al., 2011). An interaction between the Val and Met alleles and the quality of parental care on cognitive function has also been reported in infants. Infants with the Met allele exhibit greater cognitive ability than those with the Val allele when they are reared with good parental care, and the opposite relationship is observed with poor paternal care (Voelker et al., 2009). An interaction between the Val and Met alleles and early childhood adversity on anxiety has also been reported; Met-allele carriers who have experienced severe childhood adversity exhibit more anxiety than those without such experience; however, this effect is absent in Val-allele carriers (Baumann et al., 2013). The effects of an interaction between early stress experiences and the Val and Met alleles on working memory have been reported, although this finding has been contradicted in other cases (Ursini et al., 2011). Thus, Val-allele carriers exhibit worse performances in the working memory tests than Met-allele carriers, and this effect is further worsened in Val-allele carriers with early stress experiences.

Collectively, the alleles in the DA and 5-HT genes that are associated with increased risks of psychotic and mood disorders could be favorably selected for when early developmental environmental conditions are adverse. By this selection, the diversity of the genetic pools may be secured to prepare for future adverse environments that are anticipated in subsequent generations. This process may involve epigenetic mechanisms as suggested by a study that reported that maternal care may alter glucocorticoid receptor expression in the hippocampus, which in turn reduces anxiety and stress responses through epigenetic mechanisms (Weaver et al., 2004). Consistent with this finding, early stress experiences have been demonstrated to decrease DNA methylation on the SNP site of the COMT gene (Abdolmaleky et al., 2006; Ursini et al., 2011).

\section{Other Potential Mechanisms}

Here, we discuss two additional mechanisms that still remains more speculative due to the limited evidence. One of these mechanisms is the selection of alleles based on the construction of friendship networks in which subjects of the same genotypes tend to make friends. The other mechanism is the selection of alleles based on symbiosis with parasitic protozoans and gut microbiota that produce neurotransmitters and thereby influence the neural activities of their hosts.

\subsection{Social Network Homophily as an Evolutionary Origin of Psychotic and Mood Disorders}

Accumulating evidence suggests that individuals with similar personalities and behavioral traits tend to coordinate friendships, which is known as homophily. For example, higher incidences of obesity (Christakis and Fowler, 2007), drug abuse (Christakis and Fowler, 2008; Rosenquist et al., 2010; Shakya et al., 2012), and emotional states, such as happiness (Fowler and Christakis, 2008) and depression (Rosenquist et al., 2011), are observed between friends than between strangers. The genetic backgrounds of subjects have been demonstrated to play important roles in such friendship network homophily. Thus, subjects with the same (homophilous) or opposite (heterophilous) genotypes tend to create friendships (Christakis and Fowler, 2014). One such genotype that is involved in social network homophily in human subjects is that of DRD2 (Fowler et al., 2011). In non-human primates, friendship 
network homophily as determined by affiliative contact, such as grooming between subjects, has been associated with 5HTTLPR and TPH2 alleles (Brent et al., 2013).

Upon consideration of these studies, it is plausible that alleles associated with increased risks of psychotic and mood disorders may be maintained in social networks that are organized by people who have the same alleles. This notion is consistent with an argument that we recently proposed; i.e., psychiatric disorders may not necessarily work disadvantageously among afflicted individuals in a social network conditions that consist only of afflicted individuals (Lee and Goto, 2013). It is also important to note that friendship and mate choice are functionally different, and mate choice but not friendship is crucial for the functioning of selection. Nonetheless, because no gender specificity has been observed in the organization of friendships among individuals with the the same genotypes, assortative mate choice may indeed occur through the extension of male-female friendships. This notion is supported by a recent study that concluded that nonrandom mating is evident in psychiatric populations both within specific disorders and across the spectrum of psychiatric condition, such that in regard to choosing a partner, people actually tend to pair up with those similar to them; i.e., partners tend to be more alike in their psychiatric statuses. (Nordsletten et al., 2016).

\subsection{Symbiosis as an Evolutionary Origin of Psychotic and Mood Disorders}

DA function follows the Yerkes-Dodson law; i.e., both DA concentrations that are too low or too high cause dysfunction (Seamans and Yang, 2004). Thus, environmental conditions that increase DA release may favorably work for carriers of a genetic variant that leads to low basal DA concentrations (e.g. the COMT Val allele), whereas the same environmental conditions would produce detrimental effects for subjects with genetic variants that cause high basal DA levels (e.g. the COMT Met allele). One such environmental factor may be Toxoplasma Gondii (T. Gondii). T. Gondii is a parasitic protozoan that penetrates the blood-brain barrier and forms cysts in the central nervous system (Montoya and Liesenfeld, 2004). Offspring born to mothers infected with T. Gondii have been demonstrated to be at an increased risk of SCZ (Brown et al., 2005). Rodents infected with T. Gondii have been found to exhibit increased DA concentrations in brain regions such as the limbic structures (Stibbs, 1985). These increases appear to be associated with a mechanism involving the fact that $\mathrm{T}$. Gondii has its own rate-limiting enzyme for catecholamine synthesis, i.e., tyrosine hydroxylase (Gaskell et al., 2009). Thus, the DA synthesized in the T. Gondii cysts may be released into infected regions.

Accumulating evidence suggests that neural activity is also subject to a significant influence of the gut microbiota (Mayer et al., 2014). In rodents, infection with a sub-clinical dose of campylobacter jejuni has been demonstrated to heighten anxiety (Goehler et al., 2008; Lyte et al., 1998), whereas probiotics, such as lactobacillis (Bravo et al., 2011) and bifidobacterium (Bercik et al., 2011), attenuate anxiety. Infection with the parasitic nematode Trichuris muris decreases brain-derived neurotrophic factor (BDNF) expression in the hippocampus, which is reversed by the promotion of gut bifidobacterium (Bercik et al., 2010). In human subjects, the consumption of fermented milk foods for 4 weeks has been demonstrated to attenuate emotional responses and anxiety in addition to altering cortical neuronal network activity in response to negative stimuli (Messaoudi et al., 2011; Tillisch et al., 2013). Lyte proposed that the neurotransmitter molecules synthesized by microbiota, including 
DA (by bacillus and serratia) and 5-HT (by candida, streptococcus, escherichia, and enterococcus), may be transported into the central nervous system and affect neuronal activity (Lyte et al., 2011). Studies have also revealed that the composition of the gut microbiota significantly depends on the genotype (Khachatryan et al., 2008) and ethnic group (De Filippo et al., 2010) of the host.

Collectively, symbiosis with these parasitic protozoans and gut microbiota may also affect the selection of alleles associated with psychotic and mood disorders.

\section{Conclusions}

We have presented the following biological mechanisms that may explain the selection of DA and 5-HT alleles that are associated with increased risks of psychotic and mood disorders: (1) social competitiveness/hierarchy, (2) maternal care, (3) social network homophily, and (4) symbiosis. Presently, various psychotic and mood disorder candidate genes have already been identified. The specific genetic variants of DA and 5-HT genes associated with increased risks of psychotic and mood disorders mentioned in this article are summarized in Table 1. Although they cause disadvantageous phenotypes, these alleles have not been extinguished from the population. Although psychotic and mood disorders may be byproducts of the evolution of brain function on the one hand, these disorders can also be understood as evolutionary adaptations that have been maintained under specific environmental conditions on the other hand. Consequently, the presence of psychotic and mood disorders could retain population diversity that enables preparation for adverse environmental conditions that are anticipated in future generations. Investigations of the biological mechanisms of psychotic and mood disorders from the evolutionary perspective are a promising new venue of research.

\section{Acknowledgements}

We thank Drs. Robert Dielenberg, Nobumichi Hozumi, Satoru Otani, and colleagues in the Institute of Seizon and Life Sciences and Kyoto University for helpful discussions. 


\section{References}

Abdolmaleky, H.M., Cheng, K.H., Faraone, S.V., Wilcox, M., Glatt, S.J., Gao, F., Smith, C.L., Shafa, R., Aeali, B., Carnevale, J., Pan, H., Papageorgis, P., Ponte, J.F., Sivaraman, V., Tsuang, M.T., Thiagalingam, S., 2006. Hypomethylation of MB-COMT promoter is a major risk factor for schizophrenia and bipolar disorder. Hum Mol Genet 15, 3132-3145.

Abi-Dargham, A., Xu, X., Thompson, J.L., Gil, R., Kegeles, L.S., Urban, N., Narendran, R., Hwang, D.R., Laruelle, M., Slifstein, M., 2012. Increased prefrontal cortical $\mathrm{D}$ (1) receptors in drug naive patients with schizophrenia: a PET study with [(1)(1)C]NNC112. J Psychopharmacol 26, 794-805.

Allen, N.C., Bagade, S., McQueen, M.B., Ioannidis, J.P., Kavvoura, F.K., Khoury, M.J., Tanzi, R.E., Bertram, L., 2008. Systematic meta-analyses and field synopsis of genetic association studies in schizophrenia: the SzGene database. Nat Genet 40, 827-834.

Ansorge, M.S., Hen, R., Gingrich, J.A., 2007. Neurodevelopmental origins of depressive disorders. Curr Opin Pharmacol 7, 8-17.

Arnsten, A.F., Rubia, K., 2012. Neurobiological circuits regulating attention, cognitive control, motivation, and emotion: disruptions in neurodevelopmental psychiatric disorders. J Am Acad Child Adolesc Psychiatry 51, 356-367.

Bakermans-Kranenburg, M.J., van Ijzendoorn, M.H., 2006. Gene-environment interaction of the dopamine D4 receptor (DRD4) and observed maternal insensitivity predicting externalizing behavior in preschoolers. Dev Psychobiol 48, 406-409.

Barnett, J.H., Jones, P.B., Robbins, T.W., Muller, U., 2007. Effects of the catechol-O-methyltransferase Val158Met polymorphism on executive function: a meta-analysis of the Wisconsin Card Sort Test in schizophrenia and healthy controls. Mol Psychiatry 12, 502-509.

Barnett, J.H., Scoriels, L., Munafo, M.R., 2008. Meta-analysis of the cognitive effects of the catechol-O-methyltransferase gene Val158/108Met polymorphism. Biol Psychiatry 64, 137-144.

Barr, C.S., Newman, T.K., Shannon, C., Parker, C., Dvoskin, R.L., Becker, M.L., Schwandt, M., Champoux, M., Lesch, K.P., Goldman, D., Suomi, S.J., Higley, J.D., 2004. Rearing condition and rh5-HTTLPR interact to influence limbic-hypothalamic-pituitary-adrenal axis response to stress in infant macaques. Biol Psychiatry 55, 733-738.

Baumann, C., Klauke, B., Weber, H., Domschke, K., Zwanzger, P., Pauli, P., Deckert, J., Reif, A., 2013. The interaction of early life experiences with COMT val158met affects anxiety sensitivity. Gene Brai Behav 12, 821-829.

Belsky, J., Hartman, S., 2014. Gene-environment interaction in evolutionary perspective: differential susceptibility to environmental influences. World Psychiatry 13, 87-89.

Belsky, J., Jonassaint, C., Pluess, M., Stanton, M., Brummett, B., Williams, R., 2009. Vulnerability genes or plasticity genes? Mol Psychiatry 14, 746-754.

Bennett, P.J., McMahon, W.M., Watabe, J., Achilles, J., Bacon, M., Coon, H., Grey, T., Keller, T., Tate, D., Tcaciuc, I., Workman, J., Gray, D., 2000. Tryptophan hydroxylase polymorphisms in suicide victims. Psychiatr Genet 10, 13-17.

Benson-Amram, S., Holekamp, K.E., 2012. Innovative problem solving by wild spotted 
hyenas. Royal Soc Proc Biol Sci 279, 4087-4095.

Bercik, P., Park, A.J., Sinclair, D., Khoshdel, A., Lu, J., Huang, X., Deng, Y., Blennerhassett, P.A., Fahnestock, M., Moine, D., Berger, B., Huizinga, J.D., Kunze, W., McLean, P.G., Bergonzelli, G.E., Collins, S.M., Verdu, E.F., 2011. The anxiolytic effect of Bifidobacterium longum NCC3001 involves vagal pathways for gut-brain communication. Neurogastroenterol 23, 1132-1139.

Bercik, P., Verdu, E.F., Foster, J.A., Macri, J., Potter, M., Huang, X., Malinowski, P., Jackson, W., Blennerhassett, P., Neufeld, K.A., Lu, J., Khan, W.I., Corthesy-Theulaz, I., Cherbut, C., Bergonzelli, G.E., Collins, S.M., 2010. Chronic gastrointestinal inflammation induces anxiety-like behavior and alters central nervous system biochemistry in mice. Gastroenterol 139, 2102-2112 e2101.

Berrios, G.E., 1988. Melancholia and depression during the 19th century: a conceptual history. Br J Psychiatry 153, 298-304.

Berry, D., McCartney, K., Petrill, S., Deater-Deckard, K., Blair, C., 2014. Gene-environment interaction between DRD4 7-repeat VNTR and early child-care experiences predicts self-regulation abilities in prekindergarten. Dev psychobiol 56, 373-391.

Betcheva, E.T., Mushiroda, T., Takahashi, A., Kubo, M., Karachanak, S.K., Zaharieva, I.T., Vazharova, R.V., Dimova, II, Milanova, V.K., Tolev, T., Kirov, G., Owen, M.J., O'Donovan, M.C., Kamatani, N., Nakamura, Y., Toncheva, D.I., 2009. Case-control association study of 59 candidate genes reveals the DRD2 SNP rs6277 (C957T) as the only susceptibility factor for schizophrenia in the Bulgarian population. J Hum Genet 54, 98-107.

Beutler, E., Dern, R.J., Flanagan, C.L., 1955. Effect of sickle-cell trait on resistance to malaria. Br Med J 1, 1189-1191.

Bouchard, J., Goodyer, W., Lefebvre, L., 2007. Social learning and innovation are positively correlated in pigeons (Columba livia). Anim Cogn 10, 259-266.

Bravo, J.A., Forsythe, P., Chew, M.V., Escaravage, E., Savignac, H.M., Dinan, T.G., Bienenstock, J., Cryan, J.F., 2011. Ingestion of Lactobacillus strain regulates emotional behavior and central GABA receptor expression in a mouse via the vagus nerve. Proc Natl Acad Sci USA 108, 16050-16055.

Brennan, P.A., Hammen, C., Sylvers, P., Bor, W., Najman, J., Lind, P., Montgomery, G., Smith, A.K., 2011. Interactions between the COMT Val108/158Met polymorphism and maternal prenatal smoking predict aggressive behavior outcomes. Biol Psychol 87, 99-105.

Brent, L.J., Heilbronner, S.R., Horvath, J.E., Gonzalez-Martinez, J., Ruiz-Lambides, A., Robinson, A.G., Skene, J.H., Platt, M.L., 2013. Genetic origins of social networks in rhesus macaques. Sci Rep 3, 1042.

Brown, A.S., Schaefer, C.A., Quesenberry, C.P., Jr., Liu, L., Babulas, V.P., Susser, E.S., 2005. Maternal exposure to toxoplasmosis and risk of schizophrenia in adult offspring. Am J Psychiatry 162, 767-773.

Burt, S.A., 2009. Rethinking environmental contributions to child and adolescent psychopathology: a meta-analysis of shared environmental influences. Psychol Bull 135, 608-637.

Camus, S.M., Rochais, C., Blois-Heulin, C., Li, Q., Hausberger, M., Bezard, E., 2014. Depressive-like behavioral profiles in captive-bred single- and socially-housed rhesus and cynomolgus macaques: a species comparison. Front Behav Neurosci 8, 
47.

Canli, T., Lesch, K.P., 2007. Long story short: the serotonin transporter in emotion regulation and social cognition. Nat Neurosci 10, 1103-1109.

Cervenka, S., Gustavsson, J.P., Halldin, C., Farde, L., 2010. Association between striatal and extrastriatal dopamine D2-receptor binding and social desirability. NeuroImage 50, 323-328.

Chajkowski-Scarry, S., Rimoldi, J.M., 2014. Monoamine oxidase A and B substrates: probing the pathway for drug development. Fut Med Chem 6, 697-717.

Champoux, M., Bennett, A., Shannon, C., Higley, J.D., Lesch, K.P., Suomi, S.J., 2002. Serotonin transporter gene polymorphism, differential early rearing, and behavior in rhesus monkey neonates. Mo Psychiatry 7, 1058-1063.

Chase, I.D., Tovey, C., Spangler-Martin, D., Manfredonia, M., 2002. Individual differences versus social dynamics in the formation of animal dominance hierarchies. Proc Natl Acad Sci USA 99, 5744-5749.

Chen, C., Burton, M., Greenberger, E., Dmitrieva, J., 1999. Population migration and the variation of dopamine D4 receptor (DRD4) allele frequencies around the globe. Evol Hum Behav 20, 309-324.

Christakis, N.A., Fowler, J.H., 2007. The spread of obesity in a large social network over 32 years. N Engl J Med 357, 370-379.

Christakis, N.A., Fowler, J.H., 2008. The collective dynamics of smoking in a large social network. N Engl J Med 358, 2249-2258.

Christakis, N.A., Fowler, J.H., 2014. Friendship and natural selection. Proc Natl Acad Sci USA 111 Suppl 3, 10796-10801.

Cicchetti, D., Rogosch, F.A., Sturge-Apple, M.L., 2007. Interactions of child maltreatment and serotonin transporter and monoamine oxidase A polymorphisms: depressive symptomatology among adolescents from low socioeconomic status backgrounds. Dev Psychopathol 19, 1161-1180.

Clark, L., Chamberlain, S.R., Sahakian, B.J., 2009. Neurocognitive mechanisms in depression: implications for treatment. Ann Rev Neurosci 32, 57-74.

Clarke, H., Flint, J., Attwood, A.S., Munafo, M.R., 2010. Association of the 5- HTTLPR genotype and unipolar depression: a meta-analysis. Psychol Med 40, 1767-1778.

Cordeiro, Q., Siqueira-Roberto, J., Zung, S., Vallada, H., 2009. Association between the DRD2-141C Insertion/Deletion polymorphism and schizophrenia. Arquiv Neuro-psiquiatria 67, 191-194.

Corominas-Murtra, B., Goni, J., Sole, R.V., Rodriguez-Caso, C., 2013. On the origins of hierarchy in complex networks. Proc Natl Acad Sci USA 110, 13316-13321.

Couppis, M.H., Kennedy, C.H., Stanwood, G.D., 2008. Differences in aggressive behavior and in the mesocorticolimbic DA system between $\mathrm{A} / \mathrm{J}$ and BALB/cJ mice. Synapse 62, 715-724.

Courtet, P., Gottesman, II, Jollant, F., Gould, T.D., 2011. The neuroscience of suicidal behaviors: what can we expect from endophenotype strategies? Transl Psychiatry 1.

Crespi, B., Summers, K., Dorus, S., 2007. Adaptive evolution of genes underlying schizophrenia. Royal Soc Proc Biol Sci 274, 2801-2810.

Cuccaro, M.L., Shao, Y., Bass, M.P., Abramson, R.K., Ravan, S.A., Wright, H.H., Wolpert, C.M., Donnelly, S.L., Pericak-Vance, M.A., 2003. Behavioral comparisons in autistic individuals from multiplex and singleton families. J Autism 
Dev Disord 33, 87-91.

David-Barrett, T., Dunbar, R.I., 2012. Cooperation, behavioural synchrony and status in social networks. J Theor biol 308, 88-95.

Davis, K.L., Kahn, R.S., Ko, G., Davidson, M., 1991. Dopamine in schizophrenia: a review and reconceptualization. Am J Psychiatry 148, 1474-1486.

Dayan, P., Huys, Q.J., 2009. Serotonin in affective control. Ann Rev Neurosci 32, 95-126.

de Brettes, B., Berlin, I., Laurent, C., Lepine, J., Mallet, J., Puech, A., 1998. The dopamine D2 receptor gene TaqI A polymorphism is not associated with Novelty Seeking, Harm Avoidance and Reward Dependence in healthy subjects. Eur Psychiatry 13, 427-430.

De Filippo, C., Cavalieri, D., Di Paola, M., Ramazzotti, M., Poullet, J.B., Massart, S., Collini, S., Pieraccini, G., Lionetti, P., 2010. Impact of diet in shaping gut microbiota revealed by a comparative study in children from Europe and rural Africa. Proc Natl Acad Sci USA 107, 14691-14696.

de Manzano, O., Cervenka, S., Karabanov, A., Farde, L., Ullen, F., 2010. Thinking outside a less intact box: thalamic dopamine D2 receptor densities are negatively related to psychometric creativity in healthy individuals. PloS One 5, e10670.

De Simoni, M.G., Sokola, A., Fodritto, F., Dal Toso, G., Algeri, S., 1987. Functional meaning of tryptophan-induced increase of 5-HT metabolism as clarified by in vivo voltammetry. Brain Res 411, 89-94.

Dickinson, D., Elvevag, B., 2009. Genes, cognition and brain through a COMT lens. Neurosci 164, 72-87.

Dunnett, S.B., Robbins, T.W., 1992. The functional role of mesotelencephalic dopamine systems. Biol Rev Cambridge Philosophical Soc 67, 491-518.

Durand, E., Petit, O., Tremblay, L., Zimmer, C., Sgambato-Faure, V., Chassain, C., Laurent, M., Pereira, B., Silberberg, C., Durif, F., 2015. Social behavioral changes in MPTP-treated monkey model of Parkinson's disease. Front Behav Neurosci 9, 42.

Dykes, M., McGhie, A., 1976. A comparative study of attentional strategies of schizophrenic and highly creative normal subjects. Br J Psychiatry 128, 50-56.

Eaton, W.W., Martins, S.S., Nestadt, G., Bienvenu, O.J., Clarke, D., Alexandre, P., 2008. The burden of mental disorders. Epidemiol Rev 30, 1-14.

Ebstein, R.P., Novick, O., Umansky, R., Priel, B., Osher, Y., Blaine, D., Bennett, E.R., Nemanov, L., Katz, M., Belmaker, R.H., 1996. Dopamine D4 receptor (D4DR) exon III polymorphism associated with the human personality trait of Novelty Seeking. Nat Genet 12, 78-80.

Elliott, R., Zahn, R., Deakin, J.F., Anderson, I.M., 2011. Affective cognition and its disruption in mood disorders. Neuropsychopharmacol 36, 153-182.

Ellis, L., 1995. Dominance and reproductive success among nonhuman animals: a cross-species comparison. Ethol Sociobiol 16, 257-333.

Elsworth, J.D., Leahy, D.J., Roth, R.H., Redmond, D.E., Jr., 1987. Homovanillic acid concentrations in brain, CSF and plasma as indicators of central dopamine function in primates. J Neural Transm 68, 51-62.

Enoch, M.A., Steer, C.D., Newman, T.K., Gibson, N., Goldman, D., 2010. Early life stress, MAOA, and gene-environment interactions predict behavioral disinhibition in children. Gene Brain Behav 9, 65-74. 
Fairbanks, L.A., Jorgensen, M.J., Huff, A., Blau, K., Hung, Y.Y., Mann, J.J., 2004. Adolescent impulsivity predicts adult dominance attainment in male vervet monkeys. Am J Primatol 64, 1-17.

Fairbanks, L.A., Melega, W.P., Jorgensen, M.J., Kaplan, J.R., McGuire, M.T., 2001. Social impulsivity inversely associated with CSF 5-HIAA and fluoxetine exposure in vervet monkeys. Neuropsychopharmacol 24, 370-378.

Fan, H., Zhang, F., Xu, Y., Huang, X., Sun, G., Song, Y., Long, H., Liu, P., 2010a. An association study of DRD2 gene polymorphisms with schizophrenia in a Chinese Han population. Neurosci Lett 477, 53-56.

Fan, J.B., Zhang, C.S., Gu, N.F., Li, X.W., Sun, W.W., Wang, H.Y., Feng, G.Y., St Clair, D., He, L., 2005. Catechol-O-methyltransferase gene Val/Met functional polymorphism and risk of schizophrenia: a large-scale association study plus meta-analysis. Biol Psychiatry 57, 139-144.

Fan, M., Liu, B., Jiang, T., Jiang, X., Zhao, H., Zhang, J., 2010b. Meta-analysis of the association between the monoamine oxidase-A gene and mood disorders. Psychiatr Genet 20, 1-7.

Faraone, S.V., Doyle, A.E., Mick, E., Biederman, J., 2001. Meta-analysis of the association between the 7-repeat allele of the dopamine $\mathrm{D}(4)$ receptor gene and attention deficit hyperactivity disorder. Am J Psychiatry 158, 1052-1057.

Ferrari, P.F., Palanza, P., Parmigiani, S., Rodgers, R.J., 1998. Interindividual variability in Swiss male mice: relationship between social factors, aggression, and anxiety. Physiol Behav 63, 821-827.

Fowler, J.H., Christakis, N.A., 2008. Dynamic spread of happiness in a large social network: longitudinal analysis over 20 years in the Framingham Heart Study. BMJ 337, a2338.

Fowler, J.H., Settle, J.E., Christakis, N.A., 2011. Correlated genotypes in friendship networks. Proc Natl Acad Sci USA 108, 1993-1997.

Franz, M., McLean, E., Tung, J., Altmann, J., Alberts, S.C., 2015. Self-organizing dominance hierarchies in a wild primate population. Royal Soc Proc Biol Sci 282.

Gainetdinov, R.R., 2008. Dopamine transporter mutant mice in experimental neuropharmacology. Naunyn-Schmiedeberg Arch Pharmacol 377, 301-313.

Gao, J., Pan, Z., Jiao, Z., Li, F., Zhao, G., Wei, Q., Pan, F., Evangelou, E., 2012. TPH2 gene polymorphisms and major depression--a meta-analysis. PloS One 7, e36721.

Gaskell, E.A., Smith, J.E., Pinney, J.W., Westhead, D.R., McConkey, G.A., 2009. A unique dual activity amino acid hydroxylase in Toxoplasma gondii. PloS One 4, e4801.

Gasparini, M., Fabrizio, E., Bonifati, V., Meco, G., 1997. Cognitive improvement during Tolcapone treatment in Parkinson's disease. J Neural Transm 104, 887-894.

Gatt, J.M., Burton, K.L., Williams, L.M., Schofield, P.R., 2015. Specific and common genes implicated across major mental disorders: a review of meta-analysis studies. J Psychiat Res 60, 1-13.

Gizatullin, R., Zaboli, G., Jonsson, E.G., Asberg, M., Leopardi, R., 2006. Haplotype analysis reveals tryptophan hydroxylase (TPH) 1 gene variants associated with major depression. Biol Psychiatry 59, 295-300.

Glatt, S.J., Faraone, S.V., Tsuang, M.T., 2003a. Association between a functional catechol O-methyltransferase gene polymorphism and schizophrenia: meta-analysis of case-control and family-based studies. Am J Psychiatry 160, 
469-476.

Glatt, S.J., Faraone, S.V., Tsuang, M.T., 2003b. Schizophrenia is not associated with DRD4 48-base-pair-repeat length or individual alleles: results of a meta-analysis. Biol Psychiatry 54, 629-635.

Glatt, S.J., Jonsson, E.G., 2006. The Cys allele of the DRD2 Ser311Cys polymorphism has a dominant effect on risk for schizophrenia: evidence from fixed- and random-effects meta-analyses. American journal of medical genetics. Part B, Neuropsychiatric genetics : the official publication of the International Society of Psychiatr Genet 141B, 149-154.

Gluckman, P.D., Low, F.M., Buklijas, T., Hanson, M.A., Beedle, A.S., 2011. How evolutionary principles improve the understanding of human health and disease. Evol Appl 4, 249-263.

Goehler, L.E., Park, S.M., Opitz, N., Lyte, M., Gaykema, R.P., 2008. Campylobacter jejuni infection increases anxiety-like behavior in the holeboard: possible anatomical substrates for viscerosensory modulation of exploratory behavior. Brain Behav Immun 22, 354-366.

Goldman-Rakic, P.S., Muly, E.C., 3rd, Williams, G.V., 2000. D(1) receptors in prefrontal cells and circuits. Brain Res Rev 31, 295-301.

Goldman, D., Brown, G.L., Albaugh, B., Robin, R., Goodson, S., Trunzo, M., Akhtar, L., Lucas-Derse, S., Long, J., Linnoila, M., et al., 1993. DRD2 dopamine receptor genotype, linkage disequilibrium, and alcoholism in American Indians and other populations. Alcohol Clin Exp Res 17, 199-204.

Gonon, F., Konsman, J.P., Cohen, D., Boraud, T., 2012. Why most biomedical findings echoed by newspapers turn out to be false: the case of attention deficit hyperactivity disorder. PloS One 7, e44275.

Gowlishaw, G., Dumbar, R., 1991. Dominance rank and mating success in male primates. Anim Behav 41, 1045-1056.

Grace, A.A., Gerfen, C.R., Aston-Jones, G., 1998. Catecholamines in the central nervous system. Overview. Adv Pharmacol 42, 655-670.

Grandy, D.K., Litt, M., Allen, L., Bunzow, J.R., Marchionni, M., Makam, H., Reed, L., Magenis, R.E., Civelli, O., 1989. The human dopamine D2 receptor gene is located on chromosome 11 at q22-q23 and identifies a TaqI RFLP. Am J Hum Genet 45, 778-785.

Gratten, J., Wray, N.R., Keller, M.C., Visscher, P.M., 2014. Large-scale genomics unveils the genetic architecture of psychiatric disorders. Nat Neurosci 17, 782-790.

Haeusler, M., Schiess, R., Boeni, T., 2013. Evidence for juvenile disc herniation in a homo erectus boy skeleton. Spine 38, E123-128.

Hammen, C., 2005. Stress and depression. Ann Rev Clin Psychol 1, 293-319.

Han, D.H., Yoon, S.J., Sung, Y.H., Lee, Y.S., Kee, B.S., Lyoo, I.K., Renshaw, P.F., Cho, S.C., 2008. A preliminary study: novelty seeking, frontal executive function, and dopamine receptor (D2) TaqI A gene polymorphism in patients with methamphetamine dependence. Comprehens Psychiatry 49, 387-392.

Hariri, A.R., Drabant, E.M., Weinberger, D.R., 2006. Imaging genetics: perspectives from studies of genetically driven variation in serotonin function and corticolimbic affective processing. Biol Psychiatry 59, 888-897.

Hawi, Z., McCarron, M., Kirley, A., Daly, G., Fitzgerald, M., Gill, M., 2000. No association of the dopamine DRD4 receptor (DRD4) gene polymorphism with 
attention deficit hyperactivity disorder (ADHD) in the Irish population. Am J Med Genet 96, 268-272.

Hawley, P.H., 1999. The ontogenesis of social dominance: A strategy-based evolutionary perspective. Dev Rev 19, 97-132.

Heils, A., Teufel, A., Petri, S., Stober, G., Riederer, P., Bengel, D., Lesch, K.P., 1996. Allelic variation of human serotonin transporter gene expression. J Neurochem 66, 2621-2624.

Hill, J., Breen, G., Quinn, J., Tibu, F., Sharp, H., Pickles, A., 2013. Evidence for interplay between genes and maternal stress in utero: monoamine oxidase A polymorphism moderates effects of life events during pregnancy on infant negative emotionality at 5 weeks. Gene Brain Behav 12, 388-396.

Hobson, E.A., DeDeo, S., 2015. Social Feedback and the Emergence of Rank in Animal Society. PLoS Comput Biol 11, e1004411.

Homberg, J.R., Lesch, K.P., 2011. Looking on the bright side of serotonin transporter gene variation. Biol Psychiatry 69, 513-519.

Howes, O.D., Kapur, S., 2009. The dopamine hypothesis of schizophrenia: version III--the final common pathway. Schizophr Bull 35, 549-562.

Huizinga, D., Haberstick, B.C., Smolen, A., Menard, S., Young, S.E., Corley, R.P., Stallings, M.C., Grotpeter, J., Hewitt, J.K., 2006. Childhood maltreatment, subsequent antisocial behavior, and the role of monoamine oxidase A genotype. Biol Psychiatry 60, 677-683.

Humphreys, K.L., Zeanah, C.H., Nelson, C.A., 3rd, Fox, N.A., Drury, S.S., 2015. Serotonin Transporter Genotype (5HTTLPR) Moderates the Longitudinal Impact of Atypical Attachment on Externalizing Behavior. J Dev Behav Pediatrics 36, 409-16.

Ichimiya, T., Suhara, T., Sudo, Y., Okubo, Y., Nakayama, K., Nankai, M., Inoue, M., Yasuno, F., Takano, A., Maeda, J., Shibuya, H., 2002. Serotonin transporter binding in patients with mood disorders: a PET study with $[11 \mathrm{C}](+) \mathrm{McN} 5652$. Biol Psychiatry 51, 715-722.

Johnson, R.J., Sautin, Y.Y., Oliver, W.J., Roncal, C., Mu, W., Gabriela Sanchez-Lozada, L., Rodriguez-Iturbe, B., Nakagawa, T., Benner, S.A., 2009. Lessons from comparative physiology: could uric acid represent a physiologic alarm signal gone awry in western society? J Comp Physiol B, Biochem System Envroment Physiol $179,67-76$.

Kambeitz, J., Abi-Dargham, A., Kapur, S., Howes, O.D., 2014. Alterations in cortical and extrastriatal subcortical dopamine function in schizophrenia: systematic review and meta-analysis of imaging studies. Br J Psychiatry 204, 420-429.

Karlsson, P., Farde, L., Halldin, C., Sedvall, G., 2002. PET study of D(1) dopamine receptor binding in neuroleptic-naive patients with schizophrenia. Am J Psychiatry 159, 761-767.

Karoum, F., Chrapusta, S.J., Egan, M.F., 1994. 3-Methoxytyramine is the major metabolite of released dopamine in the rat frontal cortex: reassessment of the effects of antipsychotics on the dynamics of dopamine release and metabolism in the frontal cortex, nucleus accumbens, and striatum by a simple two pool model. $\mathrm{J}$ Neurochem 63, 972-979.

Keltikangas-Jarvinen, L., Pulkki-Raback, L., Elovainio, M., Raitakari, O.T., Viikari, J., Lehtimaki, T., 2009. DRD2 C32806T modifies the effect of child-rearing 
environment on adulthood novelty seeking. Am J Med Genet Pt B, Neuropsychiat Genet 150B, 389-394.

Khachatryan, Z.A., Ktsoyan, Z.A., Manukyan, G.P., Kelly, D., Ghazaryan, K.A., Aminov, R.I., 2008. Predominant role of host genetics in controlling the composition of gut microbiota. PloS One 3, e3064.

Kim-Cohen, J., Caspi, A., Taylor, A., Williams, B., Newcombe, R., Craig, I.W., Moffitt, T.E., 2006. MAOA, maltreatment, and gene-environment interaction predicting children's mental health: new evidence and a meta-analysis. Mol Psychiatry 11, 903-913.

Kimberg, D.Y., D'Esposito, M., Farah, M.J., 1997. Effects of bromocriptine on human subjects depend on working memory capacity. Neuroreport 8, 3581-3585.

Kimura, M., 1968. Evolutionary rate at the molecular level. Nature 217, 624-626.

Kimura, M., 1977. Preponderance of synonymous changes as evidence for the neutral theory of molecular evolution. Nature 267, 275-276.

Kimura, M., Ohta, T., 1971. Protein polymorphism as a phase of molecular evolution. Nature 229, 467-469.

Knutson, B., Wolkowitz, O.M., Cole, S.W., Chan, T., Moore, E.A., Johnson, R.C., Terpstra, J., Turner, R.A., Reus, V.I., 1998. Selective alteration of personality and social behavior by serotonergic intervention. Am J Psychiatry 155, 373-379.

Kosaka, J., Takahashi, H., Ito, H., Takano, A., Fujimura, Y., Matsumoto, R., Nozaki, S., Yasuno, F., Okubo, Y., Kishimoto, T., Suhara, T., 2010. Decreased binding of [11C]NNC112 and [11C]SCH23390 in patients with chronic schizophrenia. Life Sci 86, 814-818.

Koski, J.E., Xie, H., Olson, I.R., 2015. Understanding social hierarchies: The neural and psychological foundations of status perception. Soc Neurosci, 1-24.

Kuhar, M.J., Sanchez-Roa, P.M., Wong, D.F., Dannals, R.F., Grigoriadis, D.E., Lew, R., Milberger, M., 1990. Dopamine transporter: biochemistry, pharmacology and imaging. Eur Neurol 30 Suppl 1, 15-20.

Kupfer, D.J., Frank, E., Phillips, M.L., 2012. Major depressive disorder: new clinical, neurobiological, and treatment perspectives. Lancet 379, 1045-1055.

Kyaga, S., Landen, M., Boman, M., Hultman, C.M., Langstrom, N., Lichtenstein, P., 2013. Mental illness, suicide and creativity: 40-year prospective total population study. J Psychiatr Res 47, 83-90.

Kyziridis, T.C., 2005. Notes on the history of schizophrenia. Germ J Psychiatry 8, $42-48$

LaHoste, G.J., Swanson, J.M., Wigal, S.B., Glabe, C., Wigal, T., King, N., Kennedy, J.L., 1996. Dopamine D4 receptor gene polymorphism is associated with attention deficit hyperactivity disorder. Mol Psychiatry 1, 121-124.

Larson, E.T., Summers, C.H., 2001. Serotonin reverses dominant social status. Behav Brain Res 121, 95-102.

Lasky-Su, J.A., Faraone, S.V., Glatt, S.J., Tsuang, M.T., 2005. Meta-analysis of the association between two polymorphisms in the serotonin transporter gene and affective disorders. Am J Med Genet Pt B, Neuropsychiatr Genet 133B, 110-115.

Lee, Y.A., Goto, Y., 2013. Reconsideration of animal models of schizophrenia and other psychiatric disorders with evolutionary perspective. Me Hypotheses 81, $1120-1126$.

Lesch, K.P., Balling, U., Gross, J., Strauss, K., Wolozin, B.L., Murphy, D.L., Riederer, 
P., 1994. Organization of the human serotonin transporter gene. J Neural Transm Gen Sect 95, 157-162.

Lewis, D.A., Levitt, P., 2002. Schizophrenia as a disorder of neurodevelopment. Ann Rev Neurosci 25, 409-432.

Lewis, S.W., Reveley, A.M., Reveley, M.A., Chitkara, B., Murray, R.M., 1987. The familial/sporadic distinction as a strategy in schizophrenia research. $\mathrm{Br} \mathrm{J}$ Psychiatry 151, 306-313.

Li, D., He, L., 2008. Meta-study on association between the monoamine oxidase A gene (MAOA) and schizophrenia. American journal of medical genetics. Part B, Neuropsychiatric genetics : the official publication of the International Society of Psychiatr Genet 147B, 174-178.

Liljequist, R., Haapalinna, A., Ahlander, M., Li, Y.H., Mannisto, P.T., 1997. Catechol O-methyltransferase inhibitor tolcapone has minor influence on performance in experimental memory models in rats. Behav Brain Res 82, 195-202.

Lin, S.C., Wu, P.L., Ko, H.C., Wu, J.Y., Huang, S.Y., Lin, W.W., Lu, R.B., 2007. Specific personality traits and dopamine, serotonin genes in anxiety-depressive alcoholism among Han Chinese in Taiwan. Prog Neuro-psychopharmacol Biol Psychiatry 31, 1526-1534.

Liu, L., Fan, D., Ding, N., Hu, Y., Cai, G., Wang, L., Xin, L., Xia, Q., Li, X., Xu, S., Xu, J., Yang, X., Zou, Y., Pan, F., 2014. The relationship between DRD2 gene polymorphisms (C957T and C939T) and schizophrenia: a meta-analysis. Neurosci Lett 583, 43-48.

Liu, Z.W., Liu, J.L., An, Y., Zhang, L., Wang, Y.M., 2012. Association between Ser311Cys polymorphism in the dopamine D2 receptor gene and schizophrenia risk: a meta-analysis in Asian populations. Genet Mol Res 11, 261-270.

Lopez Leon, S., Croes, E.A., Sayed-Tabatabaei, F.A., Claes, S., Van Broeckhoven, C., van Duijn, C.M., 2005. The dopamine D4 receptor gene 48-base-pair-repeat polymorphism and mood disorders: a meta-analysis. Biol Psychiatry 57, 999-1003.

Lotrich, F.E., Pollock, B.G., 2004. Meta-analysis of serotonin transporter polymorphisms and affective disorders. Psychiatr Genet 14, 121-129.

Luciana, M., Depue, R.A., Arbisi, P., Leon, A., 1992. Facilitation of working memory in humans by a d2 dopamine receptor agonist. J Cog Neurosci 4, 58-68.

Lyte, M., Varcoe, J.J., Bailey, M.T., 1998. Anxiogenic effect of subclinical bacterial infection in mice in the absence of overt immune activation. Physiol Behav 65, 63-68.

Lyte, M., Vulchanova, L., Brown, D.R., 2011. Stress at the intestinal surface: catecholamines and mucosa-bacteria interactions. Cell Tiss Res 343, 23-32.

Machida, T., Yonezawa, Y., Noumura, T., 1981. Age-associated changes in plasma testosterone levels in male mice and their relation to social dominance or subordinance. Horm Behav 15, 238-245.

Majolo, B., Lehmann, J., de Bortoli Vizioli, A., Schino, G., 2012. Fitness-related benefits of dominance in primates. Am J Phys Anthropol 147, 652-660.

Malhotra, A.K., Kestler, L.J., Mazzanti, C., Bates, J.A., Goldberg, T., Goldman, D., 2002. A functional polymorphism in the COMT gene and performance on a test of prefrontal cognition. Am J Psychiatry 159, 652-654.

Malhotra, D., Sebat, J., 2012. CNVs: harbingers of a rare variant revolution in psychiatric genetics. Cell 148, 1223-1241. 
Mandell, A.J., Knapp, S., 1982. Regulation of tryptophan hydroxylase: variational kinetics suggest a neuropharmacology of phase. Adv Biochem Psychopharmacol $34,1-15$.

Mann, J.J., Arango, V.A., Avenevoli, S., Brent, D.A., Champagne, F.A., Clayton, P., Currier, D., Dougherty, D.M., Haghighi, F., Hodge, S.E., Kleinman, J., Lehner, T., McMahon, F., Moscicki, E.K., Oquendo, M.A., Pandey, G.N., Pearson, J., Stanley, B., Terwilliger, J., Wenzel, A., 2009. Candidate endophenotypes for genetic studies of suicidal behavior. Biol Psychiatry 65, 556-563.

Mann, J.J., Huang, Y.Y., Underwood, M.D., Kassir, S.A., Oppenheim, S., Kelly, T.M., Dwork, A.J., Arango, V., 2000. A serotonin transporter gene promoter polymorphism (5-HTTLPR) and prefrontal cortical binding in major depression and suicide. Arch Gen Psychiatry 57, 729-738.

Martinez, D., Orlowska, D., Narendran, R., Slifstein, M., Liu, F., Kumar, D., Broft, A., Van Heertum, R., Kleber, H.D., 2010. Dopamine type $2 / 3$ receptor availability in the striatum and social status in human volunteers. Biol Psychiatry 67, 275-278.

Matthews, L.J., Butler, P.M., 2011. Novelty-seeking DRD4 polymorphisms are associated with human migration distance out-of-Africa after controlling for neutral population gene structure. Am J Phys Anthropol 145, 382-389.

Mayer, E.A., Knight, R., Mazmanian, S.K., Cryan, J.F., Tillisch, K., 2014. Gut microbes and the brain: paradigm shift in neuroscience. J Neurosci 34, 15490-15496.

Messaoudi, M., Lalonde, R., Violle, N., Javelot, H., Desor, D., Nejdi, A., Bisson, J.F., Rougeot, C., Pichelin, M., Cazaubiel, M., Cazaubiel, J.M., 2011. Assessment of psychotropic-like properties of a probiotic formulation (Lactobacillus helveticus R0052 and Bifidobacterium longum R0175) in rats and human subjects. Br J Nutr 105, 755-764.

Meyer-Lindenberg, A., Nichols, T., Callicott, J.H., Ding, J., Kolachana, B., Buckholtz, J., Mattay, V.S., Egan, M., Weinberger, D.R., 2006. Impact of complex genetic variation in COMT on human brain function. Mol Psychiatry 11, 867-877, 797.

Meyer, J.H., Houle, S., Sagrati, S., Carella, A., Hussey, D.F., Ginovart, N., Goulding, V., Kennedy, J., Wilson, A.A., 2004. Brain serotonin transporter binding potential measured with carbon 11-labeled DASB positron emission tomography: effects of major depressive episodes and severity of dysfunctional attitudes. Arch Gen Psychiatry 61, 1271-1279.

Monakhov, M., Golimbet, V., Abramova, L., Kaleda, V., Karpov, V., 2008. Association study of three polymorphisms in the dopamine D2 receptor gene and schizophrenia in the Russian population. Schizophr Res 100, 302-307.

Montoya, J.G., Liesenfeld, O., 2004. Toxoplasmosis. Lancet 363, 1965-1976.

Morgan, D., Grant, K.A., Gage, H.D., Mach, R.H., Kaplan, J.R., Prioleau, O., Nader, S.H., Buchheimer, N., Ehrenkaufer, R.L., Nader, M.A., 2002. Social dominance in monkeys: dopamine D2 receptors and cocaine self-administration. Nat Neurosci 5, 169-174.

Morgan, D., Grant, K.A., Prioleau, O.A., Nader, S.H., Kaplan, J.R., Nader, M.A., 2000. Predictors of social status in cynomolgus monkeys (Macaca fascicularis) after group formation. Am J Primatol 52, 115-131.

Moskowitz, D.S., Pinard, G., Zuroff, D.C., Annable, L., Young, S.N., 2001. The effect of tryptophan on social interaction in everyday life: a placebo-controlled study. Neuropsychopharmacol 25, 277-289. 
Muller, U., von Cramon, D.Y., Pollmann, S., 1998. D1- versus D2-receptor modulation of visuospatial working memory in humans. J Neurosci 18, 2720-2728.

Mullin, A.P., Gokhale, A., Moreno-De-Luca, A., Sanyal, S., Waddington, J.L., Faundez, V., 2013. Neurodevelopmental disorders: mechanisms and boundary definitions from genomes, interactomes and proteomes. Transl Psychiatry 3, e329.

Munafo, M.R., Bowes, L., Clark, T.G., Flint, J., 2005. Lack of association of the COMT (Val158/108 Met) gene and schizophrenia: a meta-analysis of case-control studies. Mol Psychiatry 10, 765-770.

Nader, M.A., Nader, S.H., Czoty, P.W., Riddick, N.V., Gage, H.D., Gould, R.W., Blaylock, B.L., Kaplan, J.R., Garg, P.K., Davies, H.M., Morton, D., Garg, S., Reboussin, B.A., 2012. Social dominance in female monkeys: dopamine receptor function and cocaine reinforcement. Biol Psychiatry 72, 414-421.

Newman, T.K., Syagailo, Y.V., Barr, C.S., Wendland, J.R., Champoux, M., Graessle, M., Suomi, S.J., Higley, J.D., Lesch, K.P., 2005. Monoamine oxidase A gene promoter variation and rearing experience influences aggressive behavior in rhesus monkeys. Biol Psychiatry 57, 167-172.

Nielsen, R., Hellmann, I., Hubisz, M., Bustamante, C., Clark, A.G., 2007. Recent and ongoing selection in the human genome. Nat Rev Genet 8, 857-868.

Noble, E.P., 2003. D2 dopamine receptor gene in psychiatric and neurologic disorders and its phenotypes. Am J Med Genet Pt B, Neuropsychiatr Genet 116B, 103-125.

Noble, E.P., Ozkaragoz, T.Z., Ritchie, T.L., Zhang, X., Belin, T.R., Sparkes, R.S., 1998. D2 and D4 dopamine receptor polymorphisms and personality. Am J Med Gene 81, 257-267.

Nordsletten, A.E., Larsson, H., Crowley, J.J., Almqvist, C., Lichtenstein, P., Mataix-Cols, D., 2016. Patterns of Nonrandom Mating Within and Across 11 Major Psychiatric Disorders. JAMA Psychiatry.

O'Fallon, B.D., Fehren-Schmitz, L., 2011. Native Americans experienced a strong population bottleneck coincident with European contact. Proc Natl Acad Sci USA 108, 20444-20448.

Ogawa, L.M., Vallender, E.J., 2014. Evolutionary conservation in genes underlying human psychiatric disorders. Front Hum Neurosci 8, 283.

Okubo, Y., Suhara, T., Suzuki, K., Kobayashi, K., Inoue, O., Terasaki, O., Someya, Y., Sassa, T., Sudo, Y., Matsushima, E., Iyo, M., Tateno, Y., Toru, M., 1997. Decreased prefrontal dopamine D1 receptors in schizophrenia revealed by PET. Nature 385, 634-636.

Ouzier, M., 2013. Impulsivity in schizophrenia: A comprehensive update. Aggress Viol Behav 18, 247-254.

Pan, Y., Yao, J., Wang, B., 2014. Association of dopamine D1 receptor gene polymorphism with schizophrenia: a meta-analysis. Neuropsychiatr Dis Treat 10, 1133-1139.

Plaven-Sigray, P., Gustavsson, P., Farde, L., Borg, J., Stenkrona, P., Nyberg, L., Backman, L., Cervenka, S., 2014. Dopamine D1 receptor availability is related to social behavior: A positron emission tomography study. NeuroImage $102 \mathrm{Pt} 2$, 590-595.

Poels, E.M., Girgis, R.R., Thompson, J.L., Slifstein, M., Abi-Dargham, A., 2013. In vivo binding of the dopamine-1 receptor PET tracers [(1)(1)C]NNC112 and [(1)(1)C]SCH23390: a comparison study in individuals with schizophrenia. 
Psychopharmacol 228, 167-174.

Pohjalainen, T., Rinne, J.O., Nagren, K., Lehikoinen, P., Anttila, K., Syvalahti, E.K., Hietala, J., 1998. The A1 allele of the human D2 dopamine receptor gene predicts low D2 receptor availability in healthy volunteers. Mol Psychiatry 3, 256-260.

Power, R.A., Kyaga, S., Uher, R., MacCabe, J.H., Langstrom, N., Landen, M., McGuffin, P., Lewis, C.M., Lichtenstein, P., Svensson, A.C., 2013. Fecundity of patients with schizophrenia, autism, bipolar disorder, depression, anorexia nervosa, or substance abuse vs their unaffected siblings. JAMA Psychiatry 70, 22-30.

Power, R.A., Steinberg, S., Bjornsdottir, G., Rietveld, C.A., Abdellaoui, A., Nivard, M.M., Johannesson, M., Galesloot, T.E., Hottenga, J.J., Willemsen, G., Cesarini, D., Benjamin, D.J., Magnusson, P.K., Ullen, F., Tiemeier, H., Hofman, A., van Rooij, F.J., Walters, G.B., Sigurdsson, E., Thorgeirsson, T.E., Ingason, A., Helgason, A., Kong, A., Kiemeney, L.A., Koellinger, P., Boomsma, D.I., Gudbjartsson, D., Stefansson, H., Stefansson, K., 2015. Polygenic risk scores for schizophrenia and bipolar disorder predict creativity. Nat Neurosci 18, 953-955.

Puig, M.V., Antzoulatos, E.G., Miller, E.K., 2014. Prefrontal dopamine in associative learning and memory. Neurosci 282C, 217-229.

Rabkin, J.G., 1980. Stressful life events and schizophrenia: a review of the research literature. Psychol Bull 87, 408-425.

Ragozzino, M.E., 2002. The effects of dopamine D1 receptor blockade in the prelimbic-infralimbic areas on behavioral flexibility. Learn Mem 9, 18-28.

Raleigh, M.J., McGuire, M.T., Brammer, G.L., Pollack, D.B., Yuwiler, A., 1991. Serotonergic mechanisms promote dominance acquisition in adult male vervet monkeys. Brain Res 559, 181-190.

Rees, D.C., Williams, T.N., Gladwin, M.T., 2010. Sickle-cell disease. Lancet 376, 2018-2031.

Reuter, M., Roth, S., Holve, K., Hennig, J., 2006. Identification of first candidate genes for creativity: a pilot study. Brain Res 1069, 190-197.

Riddick, N.V., Czoty, P.W., Gage, H.D., Kaplan, J.R., Nader, S.H., Icenhower, M., Pierre, P.J., Bennett, A., Garg, P.K., Garg, S., Nader, M.A., 2009. Behavioral and neurobiological characteristics influencing social hierarchy formation in female cynomolgus monkeys. Neurosci 158, 1257-1265.

Ripke, S., O'Dushlaine, C., Chambert, K., Moran, J.L., Kahler, A.K., Akterin, S., Bergen, S.E., Collins, A.L., Crowley, J.J., Fromer, M., Kim, Y., Lee, S.H., Magnusson, P.K., Sanchez, N., Stahl, E.A., Williams, S., Wray, N.R., Xia, K., Bettella, F., Borglum, A.D., Bulik-Sullivan, B.K., Cormican, P., Craddock, N., de Leeuw, C., Durmishi, N., Gill, M., Golimbet, V., Hamshere, M.L., Holmans, P., Hougaard, D.M., Kendler, K.S., Lin, K., Morris, D.W., Mors, O., Mortensen, P.B., Neale, B.M., O'Neill, F.A., Owen, M.J., Milovancevic, M.P., Posthuma, D., Powell, J., Richards, A.L., Riley, B.P., Ruderfer, D., Rujescu, D., Sigurdsson, E., Silagadze, T., Smit, A.B., Stefansson, H., Steinberg, S., Suvisaari, J., Tosato, S., Verhage, M., Walters, J.T., Multicenter Genetic Studies of Schizophrenia, C., Levinson, D.F., Gejman, P.V., Kendler, K.S., Laurent, C., Mowry, B.J., O'Donovan, M.C., Owen, M.J., Pulver, A.E., Riley, B.P., Schwab, S.G., Wildenauer, D.B., Dudbridge, F., Holmans, P., Shi, J., Albus, M., Alexander, M., Campion, D., Cohen, D., Dikeos, D., Duan, J., Eichhammer, P., Godard, S., Hansen, M., Lerer, F.B., Liang, K.Y., Maier, W., Mallet, J., Nertney, D.A., Nestadt, G., Norton, N., O'Neill, F.A., Papadimitriou, 
G.N., Ribble, R., Sanders, A.R., Silverman, J.M., Walsh, D., Williams, N.M., Wormley, B., Psychosis Endophenotypes International, C., Arranz, M.J., Bakker, S., Bender, S., Bramon, E., Collier, D., Crespo-Facorro, B., Hall, J., Iyegbe, C., Jablensky, A., Kahn, R.S., Kalaydjieva, L., Lawrie, S., Lewis, C.M., Lin, K., Linszen, D.H., Mata, I., McIntosh, A., Murray, R.M., Ophoff, R.A., Powell, J., Rujescu, D., Van Os, J., Walshe, M., Weisbrod, M., Wiersma, D., Wellcome Trust Case Control, C., Donnelly, P., Barroso, I., Blackwell, J.M., Bramon, E., Brown, M.A., Casas, J.P., Corvin, A.P., Deloukas, P., Duncanson, A., Jankowski, J., Markus, H.S., Mathew, C.G., Palmer, C.N., Plomin, R., Rautanen, A., Sawcer, S.J., Trembath, R.C., Viswanathan, A.C., Wood, N.W., Spencer, C.C., Band, G., Bellenguez, C., Freeman, C., Hellenthal, G., Giannoulatou, E., Pirinen, M., Pearson, R.D., Strange, A., Su, Z., Vukcevic, D., Donnelly, P., Langford, C., Hunt, S.E., Edkins, S., Gwilliam, R., Blackburn, H., Bumpstead, S.J., Dronov, S., Gillman, M., Gray, E., Hammond, N., Jayakumar, A., McCann, O.T., Liddle, J., Potter, S.C., Ravindrarajah, R., Ricketts, M., Tashakkori-Ghanbaria, A., Waller, M.J., Weston, P., Widaa, S., Whittaker, P., Barroso, I., Deloukas, P., Mathew, C.G., Blackwell, J.M., Brown, M.A., Corvin, A.P., McCarthy, M.I., Spencer, C.C., Bramon, E., Corvin, A.P., O'Donovan, M.C., Stefansson, K., Scolnick, E., Purcell, S., McCarroll, S.A., Sklar, P., Hultman, C.M., Sullivan, P.F., 2013. Genome-wide association analysis identifies 13 new risk loci for schizophrenia. Nat Genet 45, 1150-1159.

Robbins, T.W., Gillan, C.M., Smith, D.G., de Wit, S., Ersche, K.D., 2012. Neurocognitive endophenotypes of impulsivity and compulsivity: towards dimensional psychiatry. Trend Cog Sci 16, 81-91.

Rodriguiz, R.M., Chu, R., Caron, M.G., Wetsel, W.C., 2004. Aberrant responses in social interaction of dopamine transporter knockout mice. Behav Brain Res 148, 185-198.

Roman, S., Zepeda-Carrillo, E.A., Moreno-Luna, L.E., Panduro, A., 2013. Alcoholism and liver disease in Mexico: genetic and environmental factors. World $\mathrm{J}$ Gastroenterol 19, 7972-7982.

Rosenquist, J.N., Fowler, J.H., Christakis, N.A., 2011. Social network determinants of depression. Mol Psychiatry 16, 273-281.

Rosenquist, J.N., Murabito, J., Fowler, J.H., Christakis, N.A., 2010. The spread of alcohol consumption behavior in a large social network. Ann Intern Med 152, 426-433, W141.

Roy, M.A., Crowe, R.R., 1994. Validity of the familial and sporadic subtypes of schizophrenia. Am J Psychiatry 151, 805-814.

Sabol, S.Z., Hu, S., Hamer, D., 1998. A functional polymorphism in the monoamine oxidase A gene promoter. Hum Genet 103, 273-279.

Schizophrenia Working Group of the Psychiatric Genomics, C., 2014. Biological insights from 108 schizophrenia-associated genetic loci. Nature 511, 421-427.

Schmitt, A., Malchow, B., Hasan, A., Falkai, P., 2014. The impact of environmental factors in severe psychiatric disorders. Front Neurosci 8, 19.

Schulke, O., Bhagavatula, J., Vigilant, L., Ostner, J., 2010. Social bonds enhance reproductive success in male macaques. Curr Biol CB 20, 2207-2210.

Seamans, J.K., Floresco, S.B., Phillips, A.G., 1998. D1 receptor modulation of hippocampal-prefrontal cortical circuits integrating spatial memory with executive 
functions in the rat. J Neurosci 18, 1613-1621.

Seamans, J.K., Yang, C.R., 2004. The principal features and mechanisms of dopamine modulation in the prefrontal cortex. Prog Neurobiol 74, 1-58.

Sedvall, G., 1990. Monoamines and schizophrenia. Act Psychiatr Scand Suppl 358, 7-13.

Seeman, P., 2011. All roads to schizophrenia lead to dopamine supersensitivity and elevated dopamine D2(high) receptors. CNS Neurosci Ther17, 118-132.

Shakya, H.B., Christakis, N.A., Fowler, J.H., 2012. Parental influence on substance use in adolescent social networks. Arch Pediatric Adolesc Med 166, 1132-1139.

Shively, C.A., Register, T.C., Higley, J.D., Willard, S.L., 2014. Sertraline effects on cerebrospinal fluid monoamines and species-typical socioemotional behavior of female cynomolgus monkeys. Psychopharmacol 231, 1409-1416.

Smillie, L.D., Cooper, A.J., Proitsi, P., Powell, J.F., Pickering, A.D., 2010. Variation in DRD2 dopamine gene predicts Extraverted personality. Neurosci Lett 468, 234-237.

Soares, J.C., Innis, R.B., 1999. Neurochemical brain imaging investigations of schizophrenia. Biol Psychiatry 46, 600-615.

Stevens, A., Price, J., 2000. Evolutionary psychiatry: A new beginning. Routledge, London, UK.

Stibbs, H.H., 1985. Changes in brain concentrations of catecholamines and indoleamines in Toxoplasma gondii infected mice. Ann Trop Med Parasitol 79, 153-157.

Suhara, T., Yasuno, F., Sudo, Y., Yamamoto, M., Inoue, M., Okubo, Y., Suzuki, K., 2001. Dopamine D2 receptors in the insular cortex and the personality trait of novelty seeking. NeuroImage 13, 891-895.

Sullivan, P.F., Daly, M.J., O'Donovan, M., 2012. Genetic architectures of psychiatric disorders: the emerging picture and its implications. Nat Rev Genet 13, 537-551.

Sullivan, P.F., Fifield, W.J., Kennedy, M.A., Mulder, R.T., Sellman, J.D., Joyce, P.R., 1998. No association between novelty seeking and the type 4 dopamine receptor gene (DRD4) in two New Zealand samples. Am J Psychiatry 155, 98-101.

Teh, L.K., Izuddin, A.F., M, H.F., Zakaria, Z.A., Salleh, M.Z., 2012. Tridimensional personalities and polymorphism of dopamine D2 receptor among heroin addicts. Biol Res Nursing 14, 188-196.

Thierry, B., 2007. Unity in diversity: Lessons from macaque societies. Evol Anthropol $16,224-238$.

Thompson, J., Thomas, N., Singleton, A., Piggott, M., Lloyd, S., Perry, E.K., Morris, C.M., Perry, R.H., Ferrier, I.N., Court, J.A., 1997. D2 dopamine receptor gene (DRD2) Taq1 A polymorphism: reduced dopamine D2 receptor binding in the human striatum associated with the A1 allele. Pharmacogenet 7, 479-484.

Tillisch, K., Labus, J., Kilpatrick, L., Jiang, Z., Stains, J., Ebrat, B., Guyonnet, D., Legrain-Raspaud, S., Trotin, B., Naliboff, B., Mayer, E.A., 2013. Consumption of fermented milk product with probiotic modulates brain activity. Gastroenterol 144, 1394-1401, 1401 e1391-1394.

Tournier, B.B., Steimer, T., Millet, P., Moulin-Sallanon, M., Vallet, P., Ibanez, V., Ginovart, N., 2013. Innately low D2 receptor availability is associated with high novelty-seeking and enhanced behavioural sensitization to amphetamine. Int $\mathbf{J}$ Neuropsychopharmacol 16, 1819-1834. 
Ursini, G., Bollati, V., Fazio, L., Porcelli, A., Iacovelli, L., Catalani, A., Sinibaldi, L., Gelao, B., Romano, R., Rampino, A., Taurisano, P., Mancini, M., Di Giorgio, A., Popolizio, T., Baccarelli, A., De Blasi, A., Blasi, G., Bertolino, A., 2011. Stress-related methylation of the catechol-O-methyltransferase Val 158 allele predicts human prefrontal cognition and activity. J Neurosci 31, 6692-6698.

van Gaalen, M.M., van Koten, R., Schoffelmeer, A.N., Vanderschuren, L.J., 2006. Critical involvement of dopaminergic neurotransmission in impulsive decision making. Biol Psychiatry 60, 66-73.

van Holstein, M., Aarts, E., van der Schaaf, M.E., Geurts, D.E., Verkes, R.J., Franke, B., van Schouwenburg, M.R., Cools, R., 2011. Human cognitive flexibility depends on dopamine D2 receptor signaling. Psychopharmacol 218, 567-578.

Van Tol, H.H., Wu, C.M., Guan, H.C., Ohara, K., Bunzow, J.R., Civelli, O., Kennedy, J., Seeman, P., Niznik, H.B., Jovanovic, V., 1992. Multiple dopamine D4 receptor variants in the human population. Nature 358, 149-152.

Voelker, P., Sheese, B.E., Rothbart, M.K., Posner, M.I., 2009. Variations in catechol-O-methyltransferase gene interact with parenting to influence attention in early development. Neurosci 164, 121-130.

Wakschlag, L.S., Kistner, E.O., Pine, D.S., Biesecker, G., Pickett, K.E., Skol, A.D., Dukic, V., Blair, R.J., Leventhal, B.L., Cox, N.J., Burns, J.L., Kasza, K.E., Wright, R.J., Cook, E.H., Jr., 2010. Interaction of prenatal exposure to cigarettes and MAOA genotype in pathways to youth antisocial behavior. Mol Psychiatry 15, 928-937.

Weaver, I.C., Cervoni, N., Champagne, F.A., D'Alessio, A.C., Sharma, S., Seckl, J.R., Dymov, S., Szyf, M., Meaney, M.J., 2004. Epigenetic programming by maternal behavior. Nat Neurosci 7, 847-854.

Westergaard, G.C., Suomi, S.J., Chavanne, T.J., Houser, L., Hurley, A., Cleveland, A., Snoy, P.J., Higley, J.D., 2003. Physiological correlates of aggression and impulsivity in free-ranging female primates. Neuropsychopharmacol 28, 1045-1055.

Xu, F., Wu, Q., Xie, L., Gong, W., Zhang, J., Zheng, P., Zhou, Q., Ji, Y., Wang, T., Li, X., Fang, L., Li, Q., Yang, D., Li, J., Melgiri, N.D., Shively, C., Xie, P., 2015. Macaques exhibit a naturally-occurring depression similar to humans. Sci Rep 5, 9220.

Yao, J., Pan, Y.Q., Ding, M., Pang, H., Wang, B.J., 2015. Association between DRD2 (rs1799732 and rs1801028) and ANKK1 (rs1800497) polymorphisms and schizophrenia: a meta-analysis. Am J Med Genet Pt B, Neuropsychiatr Genet 168B, $1-13$.

Yasuno, F., Suhara, T., Okubo, Y., Sudo, Y., Inoue, M., Ichimiya, T., Takano, A., Nakayama, K., Halldin, C., Farde, L., 2004. Low dopamine d(2) receptor binding in subregions of the thalamus in schizophrenia. Am J Psychiatry 161, 1016-1022.

Zald, D.H., Cowan, R.L., Riccardi, P., Baldwin, R.M., Ansari, M.S., Li, R., Shelby, E.S., Smith, C.E., McHugo, M., Kessler, R.M., 2008. Midbrain dopamine receptor availability is inversely associated with novelty-seeking traits in humans. JNeurosci 28, 14372-14378.

Zhang, S., Zhang, M., Zhang, J., 2014. An exploratory study on DRD2 and creative potential. Creat Res J 26, 115-123.

Zou, Y.F., Wang, F., Feng, X.L., Li, W.F., Tian, Y.H., Tao, J.H., Pan, F.M., Huang, F., 
2012. Association of DRD2 gene polymorphisms with mood disorders: a meta-analysis. J Affect Disord 136, 229-237. 
Table 1. The list of genetic variants in the DA and 5-HT genes for which meta-analyses and large scale GWAS have shown associations with psychotic and mood disorders.

\begin{tabular}{|c|c|c|c|}
\hline Genes & Variants & Disorders & References \\
\hline DRD2 & rs 2514218 & Schizophrenia & $\begin{array}{l}\text { (Schizophrenia Working Group of the } \\
\text { Psychiatric Genomics, 2014) }\end{array}$ \\
\hline & rs1801028 (Ser311Cys) & Schizophrenia & $\begin{array}{l}\text { (Yao et al., 2015) } \\
\text { (Liu et al., 2012) } \\
\text { (Glatt and Jonsson, 2006) }\end{array}$ \\
\hline & rs6277 (C957T) & Schizophrenia & $\begin{array}{l}\text { (Liu et al., 2014) } \\
\text { (Betcheva et al., 2009) } \\
\text { (Fan et al., 2010a) } \\
\text { (Monakhov et al., 2008) }\end{array}$ \\
\hline & rs1799732 (-141 Ins/Del) & Schizophrenia & (Cordeiro et al., 2009) \\
\hline & rs1800497 (TaqIA) & Mood disorder & (Zou et al., 2012) \\
\hline DRD1 & rs5326 (G-94A) & Schizophrenia & $\begin{array}{l}\text { (Pan et al., 2014) } \\
\text { (but no association in (Allen et al., } \\
2008) \text { ) }\end{array}$ \\
\hline TPH1 & rs 1800532 & Mood disorder & $\begin{array}{l}\text { (Gizatullin et al., 2006) } \\
\text { (Gatt et al., 2015) }\end{array}$ \\
\hline TPH2 & rs4570625 & Mood disorder & (Gao et al., 2012) \\
\hline 5HTT & 5HTTLPR & Mood disorder & $\begin{array}{l}\text { (Lotrich and Pollock, 2004) } \\
\text { (Lasky-Su et al., 2005) } \\
\text { (Clarke et al., 2010) }\end{array}$ \\
\hline MAOA & $\mu \mathrm{VNTR}$ & Mood disorder & (Fan et al., 2010b) \\
\hline DRD4 & 48bp VNTR & Mood disorder & (Lopez Leon et al., 2005) \\
\hline COMT & rs4860 (Val158Met) & $\begin{array}{l}\text { Schizophrenia } \\
\text { (in specific ethnicity) }\end{array}$ & $\begin{array}{l}\text { (Glatt et al., 2003a) } \\
\text { (but no association in (Fan et al., 2005) } \\
\text { and (Munafo et al., 2005)) }\end{array}$ \\
\hline
\end{tabular}

